\title{
The Four Doctrines of Self-Executing Treaties
}

Carlos Manuel Vázquez

Georgetown University Law Center, vazquez@law.georgetown.edu

Georgetown Public Law and Legal Theory Research Paper No. 12-101

This paper can be downloaded free of charge from:

https://scholarship.law.georgetown.edu/facpub/1016

http://ssrn.com/abstract=2114443

89 Am. J. Int'I L. 695-723 (1995)

This open-access article is brought to you by the Georgetown Law Library. Posted with permission of the author. Follow this and additional works at: https://scholarship.law.georgetown.edu/facpub

Part of the Constitutional Law Commons, Courts Commons, International Law Commons, and the Legislation Commons 


\title{
THE FOUR DOCTRINES OF SELF-EXECUTING TREATIES
}

\author{
By Carlos Manuel Vázquez*
}

A distinction has become entrenched in United States law between treaties that are "self-executing" and those that are not. The precise nature of this distinction-indeed, its very existence-is a matter of some controversy ${ }^{1}$ and much confusion. ${ }^{2}$ More than one lower federal court has pronounced the distinction to be the "most confounding" in the United States law of treaties. ${ }^{3} \mathrm{~A}$ tremendous amount of scholarship has sought to clarify this distinction, ${ }^{4}$ but the honest observer cannot but agree with John Jackson's observation that " $[t]$ he substantial volume of scholarly writing on this issue has not yet resolved the confusion" surrounding it. ${ }^{5}$ The continuing, and remarkably candid, judicial confusion over this issue will, I hope, excuse yet another attempt to bring some coherence to the doctrine. In this article, I argue that much of the doctrinal disarray and judicial confusion is attributable to the failure of courts and commentators to recognize that for some time four distinct "doctrines" of self-executing treaties have been masquerading as one. With a view to furthering the development of doctrine in conformity with constitutional allocations of power, I identify these four "doctrines," as reflected in the self-execution decisions of the Supreme Court and the lower federal courts, and I examine the very different types of analysis that they call for. ${ }^{6}$

At a general level, a self-executing treaty may be defined as a treaty that may be enforced in the courts without prior legislation by Congress, and a non-self-executing treaty, conversely, as a treaty that may not be enforced in the courts without prior legislative "implementation." This definition helps us understand the domestic alloca-

\footnotetext{
* Associate Professor of Law, Georgetown University Law Center. I am grateful for comments received from Brice M. Clagett, Daniel Ernst, Vicki Jackson, Laura Macklin, John Noyes, Jordan Paust, Alfred Rubin and Barbara Stark, and for the excellent research assistance of Joseph C. Bryce.

'Jordan J. Paust, Self-Executing Treaties, 82 AJIL 760 (1988); Yuji Iwasawa, The Doctrine of Self-Executing Treaties in the United States: A Cntical Analysis, 26 VA. J. INT'L. L. 627, 635 (1986).

"Sep Carlos Manuel Vázquez, Treaty-Based Rights and Remedies of Individuals, 92 Colum. L. Rev. 1082, 111723 (1992); John H. Jackson, United States, in THE EFFect OF TrEATIES IN DOMESTIC LAw 141, 148-49 (Francis G. Jacobs \& Shelley Roberts eds., 1987).

'United States v. Postal, 589 F.2d 862, 876 (5th Cir.), cert. denied, 444 U.S. 832 (1979); United States v. Noriega, 808 F.Supp. 791, 797 (S.D. Fla. 1992). The statement would be accurate even if the words "of treaties" were omitted.

In addition to the other articles cited herein, see those cited in Jackson, supra note 2, at 149 n.26.

Id. at 149 .

"This article addresses the distinction as it is drawn in United States law. Similar distinctions exist in international law, see Advisory Opinion No. 15, Jurisdiction of the Courts of Danzig, 1928 PCIJ (ser. B) No. 15 (Mar. 3), and in the laws of other nations and regional arrangements such as the European Union. The distinction has proved to be controversial and confusing in these contexts, too. See, e.g., Pierre Pescatore, The Dortnne of "Direct Effect": An Infant Disease of Community Law, 8 EUR. L. REv. 155 (1983); Josephine Steiner, Duret Applicability in EEC Law-A Chameleon Concept, 98 LAW Q. REv. 229 (1982); J. A. Winter, Direct Applicability and Direct Effect: Two Distinct and Different Concepts in Community Law, 9 CoMMON MKT. L. Rev. 425 (1972).

${ }^{7}$ See, e.g., Frolova v. Union of Soviet Socialist Republics, 761 F.2d 370, 373 (7th Gir. 1985); Tel-Oren v. L.byan Arab Republic, 726 F.2d 774, 808 (D.C. Cir. 1984) (Bork, J., concurring), cert. denied, 470 U.S. 1003 (1985); Vorhees v. Fischer \& Krecke, 697 F.2d 574, 575 (4th Cir. 1983); British Caledonian Airways v. Bond, 665 F.2d 1153, 1160 (D.C. Cir. 1981); Postal, 589 F.2d at 875; Diggs v. Richardson, 555 F.2d 848, 850-51 (D.C. Cir. 1976); Bartram v. Robertson, 15 F. 212, 213 (C.C.S.D.N.Y. 1883), affd, 122 U.S. 116 (1887); Noriega, 808 F.2d at 798; Thomas Buergenthal, Self-Executing and Non-Self-Executing Treaties in National and International Law, 235 RECUEIL DES COURS 303, 317 (1992 IV).

$\mathrm{By}$ " "enforced in the courts," I mean enforced in our domestic courts (whether state or federal) at the behest of individuals. Although treaties as a matter of international law are thought to confer rights only on states, domestic law regulates the legal relations of individuals vis-à-vis other individuals and government, and the: purpose of our domestic courts has always been thought to be the vindication of the rights of individuals,
} 
tion-of-powers function of the distinction: it allocates between the judiciary and the legislature the responsibility for enforcing compliance with treaties by everyone else (private individuals, state and federal executive officials, state legislatures). But the doctrine allocates this responsibility only provisionally. Because of the last-in-time rule, under which a statute is to be enforced by the courts even if it conflicts with an earlier treaty, ${ }^{8}$ the legislature ultimately has the power to control the judiciary's role in enforcing even self-executing treaties. ${ }^{9}$ The doctrine of self-executing treaties thus serves to distinguish those treaties that require an act of the legislature to authorize judicial enforcement from those that require an act of the legislature to remove or modify the courts' enforcement power (and duty).

Understanding the distinction's allocation-of-powers function is crucial to understanding the doctrine. It helps us frame the central question involved in any self-execution inquiry. The principal aim of this article, however, is to identify and classify the types of reasons that might legitimately lead courts to conclude that particular treaties are or are not judicially enforceable without additional legislation. To that end, I begin by examining the most relevant provision of the U.S. Constitution, the Supremacy Clause, which declares that "all Treaties [of the United States] shall be the supreme Law of the Land," and instructs the courts to give them effect. ${ }^{10}$ As shown below, this clause was adopted to minimize treaty violations attributable to the United States, a goal that the Founders sought to advance by empowering the courts to enforce treaties at the behest of affected individuals without awaiting authorization from state or federal legislatures. As the $\mathrm{Su}$ premacy Clause thus addresses the allocation-of-powers question posed by the "selfexecuting/non-self-executing" distinction, the latter distinction is ultimately a gloss on that constitutional provision. This article identifies four grounds on which a court might legitimately conclude that legislative action is necessary to authorize it to enforce a treaty, notwithstanding the Supremacy Clause. First, legislative action is necessary if the parties to the treaty (or perhaps the U.S. treaty makers alone) intended that the treaty's object

not sovereigns. See Marbury v. Madison, 5 U.S. (1 Cranch) 137, 170 (1803) ("The province of the court is, solely, to decide on the rights of individuals."). Thus, if the purpose of the Supremacy Clause (insofar as treaties are concerned) was to make treaties enforceable in the courts, as I show below and in Vázquez, supra note 2, it was perforce to make them enforceable in court at the behest of individuals. It cannot be maintained that the Founders contemplated that treaties would be enforced in our courts only at the behest of sovereign states and their officials. (For a more extended discussion of these points, see generally Vazquez, supra note 2.) Hereinafter, any reference to the enforcement or enforceability of treaties in the courts refers to their enforcement or enforceability in our domestic courts (whether state or federal) at the behest of individuals.

The recognition that treaties are (at least sometimes) enforceable in our courts at the behest of individuals raises the question of which individuals may enforce them and when. I addressed these questions at some length in Vázquez, supra note 2, and I address them further in part V infra.

${ }^{8}$ Whitney v. Robertson, 124 U.S. 190, 195 (1888); The Cherokee Tobacco, 78 U.S. (11 Wall.) 616, 62021 (1870).

${ }_{9}^{9}$ Although the last-in-time rule has been attacked as undesirable and as inconsistent with the Framers' intent insofar as it permits Congress to abrogate a treaty for domestic-law purposes, see Louis Henkin, Treaties in a Constitutional Democracy, 10 MiCH. J. INT'L L. 406, 425-26 (1989); Jules Lobel, The Limits of Corstitutional Power: Conflicts Between Foreign Policy and International Law, 71 VA. L. Rev. 1071 (1985), the Supreme Ccurt has adhered to it with notable consistency and shows no sign of rejecting it. But cf.Jordan J. Paust, Rediscovering the Relationship Between Congressional Power and International Law: Exceptions to the Last in Time Rule and the Primacy of Custom, 28 VA. J. INT"L L. 393 (1988). Because of its pedigree, and because the evidence that the rule is inconsistent with the Framers' intent is inconclusive (there appear to have been varying views on the point among the Framers), I treat the last-in-time rule as a fixed point in my analysis. See Vázquez, supra note?", at 1114 n.126.

${ }^{10}$ The Supremacy Clause, U.S. CoNST. Art. VI, cl. 2, provides as follows:

This Constitution, and the Laws of the United States which shall be made in Pursuance thereof; and all Treaties made, or which shall be made, under the Authority of the United States, shall be the supreme Law of the Land; and the Judges in every State shall be bound thereby, any Thing in the Constitution or Laws of any State to the Contrary notwithstanding. 
be accomplished through intervening acts of legislation. Second, legislative action is necessary if the norm the treaty establishes is "addressed" as a constitutional matter to the legislature. Third, legislative action is necessary if the treaty purports to accomplish what under our Constitution may be accomplished only by statute. Finally, legislation is necessary if no law confers a right of action on a plaintiff seeking to enforce the treaty.

The proposed typology leaves enormous questions unresolved. For example, what types of treaty-based norms are constitutionally addressed to the legislature? What powers does our Constitution allocate exclusively to the lawmakers? It is not the principal purpose of this article to answer these or similar questions. But any effort to bring coherence and analytical clarity to this area of the law must begin by asking the right questions, and to this end distinguishing the four doctrines of self-executing treaties is an essential first step. The four doctrines raise different questions and require different analyses. Just differentiating them would accordingly be a notable step forward.

\section{The Supremacy Clause: Its History and PuRpose in Respect to Treaties}

Since the time of our independence, treaties in Great Britain have not been thought to have the status of municipal law enforceable in common-law courts. This is attributable to allocation-of-powers concerns: treaties in Great Britain are concluded by the Crown, but enacting municipal laws is the province of Parliament. ${ }^{11}$ If a treaty contemplates that individuals will be treated in certain ways or their rights and liabilities governed by particular rules, the treaty must be "implemented" by Parliament and the required norms incorporated into municipal law by statute. Thereafter, the statute, but not the treaty itself, will be given effect by domestic law-applying officials. In other words, under the fundamental law of Great Britain, all treaties are "non-self-executing."12 All treaties,

"Ste J. G. ST, ARKE, INTRODUCTION TO INTERNATIONAL LAw 81-82 (10th ed. 1989); J. G. Collier, Is International Law Really Part of the Law of England?, 38 INT'L \& CoMP. L.Q. 924, 925-26 (1989) (citing The Parlement Belge, 4 P.D. 129 (1879)).

${ }^{1}$ The British rule was described in some detail by Justice Iredell in Ware v. Hylton, 3 U.S. (3 Dall.) 256, 274-75, rev'd on other grounds, 3 U.S. (3 Dall.) 199 (1796). (Justice Iredell's decision on Circuit was reversed because a majority of the Court disagreed with Iredell's narrow construction of the treaty. The other Justices did not take issue with Iredell's discussion of the history or purpose of the Supremacy Clause. Justice Story cited Iredell"s discussion of this history with approval in 3 JOSEPH STORY, COMMENTARIES ON THE CONSTITUTION or ture UNITEn STATES 696 (1833).) Iredell described the British rule as follows:

[I]t is an invariable practice in that country, when the King makes any stipulation [in a treaty] of a legislative nature, that it is carried into effect by an act of Parliament. The Parliament is considered as bound, upon a principle of moral obligation, to preserve the public faith, pledged by the treaty, by passing such laws as its obligation requires; but until such laws are passed, the system of law, entitled to actual obedience, remains de facto, as before.

3 U.S. (3 Dall.) at 274. Iredell gave the example of a treaty that purports to set a tariff at a given level. According to Iredell, such a treaty, despite its "self-executing" language, would not have been enforceable by British law-applying officials until implementing legislation was enacted by Parliament. Id. at 274-75. Insofar as Iredell suggested that no judges would have given effect to treaties without parliamentary implementation, he may have written too broadly, as admiralty and prize courts were empowered to give effect to the law of nations (including treaties) directly. See Alfred P. Rubin, The LaW of PIRACy 66-121 (1988). Accordingly, Iredell should probably be understood to have been describing the allocation of treaty-enforcement authority as between Parliament and the common-law courts. Cf. Harold J. Berman, The Origins of Historical Jurisprudence: Cokr, Selden, Hale, 103 YALE L.J. 1651, 1679 (1994) (attributing to Coke the "widespread notion" that "English law" meant the English common law and did not include the admiralty law or the law merchant, which were considered "foreign law").

Starke notes that there are limited exceptions to the requirement of parliamentary implementation:

No legislation is required for certain specific classes of treaties, namely, treaties modifying the belligerent rights of the Crown when engaged in maritime warfare (presumably because such treaties involve no major intrusion on the legislative domain of Parliament), and administrative agreements of an informal character needing only signature, but not ratification, provided they do not involve any alteration of municipal law. 
whatever their terms or the intent of the parties, require legislative implementation before they may be enforced by domestic law-applying officials. ${ }^{13}$

Among the pressing problems of the period of the Articles of Confederalion were the repeated violations by the states of the Treaty of Peace with Great Britain. ${ }^{14}$ The problem was aggravated by the widespread understanding during this period that the treaties concluded by the Continental Congress were not enforceable as law in the courts of the states in the face of conflicting state legislation. ${ }^{15}$ As in Great Britain, repealing acts of legislation were thought to be necessary, and very often the state legislatures neglected or refused to enact the required laws. ${ }^{16}$ Congress passed a resolution in its waning days proclaiming that treaties were "binding and obligatory" on the states even without implementing legislation, ${ }^{17}$ but this position was controversial and, in any event, the federal Government lacked a mechanism for making state courts enforce treaties. ${ }^{18}$

The repeated violation of treaties by the states was a prime concern of the Framers who gathered in Philadelphia to amend the Articles. But it was merely one facet of a more general problem: the Articles lacked a mechanism for enforcing any of the acts of the central Government, or the Articles themselves. The absence of such a mechanism was a principal reason for the Framers' decision to draft a new constitution rather than amend the Articles. The Framers considered two alternative mechanisms. The Virginia plan would have given Congress the power to "negative" state laws that contravened the Constitution, federal statutes or treaties. As applied to treaties, this plan would apparently have retained the need for an act of the legislature transforming each treaty obligation into domestic law (although it would have empowered the federal legislature to act in place of the state legislatures). The New Jersey plan, on the other hand, included a version of the Supremacy Clause, which declared the Constitution, federal laws and treaties to have automatic domestic legal force and instructed the courts to give them effect directly. Ultimately, the Framers adopted the Supremacy Clause. The clause addressed the treaty violation problem by altering the British rule:

STARKE, supra note 11 , at 82-83. Significantly, these exceptions appear to involve matters unlikely to become the subject of litigation before common-law courts.

${ }^{13}$ The constitutional rule under which all treaties are deemed to be non-self-executing will. be referred to herein as the British rule.

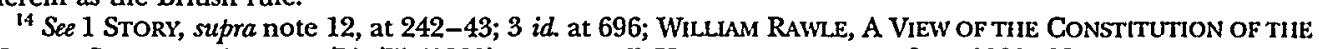
UNITED STATES OF AMERICA 74-75 (1829); see generally Vázquez, supra note 2, at 1101-02.

${ }^{15}$ See Justice Iredell's opinion in Ware, 3 U.S. (3 Dall. ) at 276. See also 3 STORY, supra note 12, at 696.

${ }^{16}$ See RAWLE, supra note 14 , at 74.

1732 Journals of THE Continental Congress 124-25, 177-84 (Mar. 21, 1787) (Roscoe R. Hill ed., 1936). The resolution declared that "on being constitutionally made[,] ratified and published [treaties] become in virtue of the confederation part of the law of the land and are not only independent of the will and power of [state] legislatures but also binding and obligatory on them." Id. at 124-25. Somewhat inconsistently, it also requested that the states enact legislation repealing laws that conflicted with treaties. $I d$. at 125 . Iredell interpreted this request as recognition that Congress lacked the power to dispense with the need for repealing legislation. See Ware, 3 U.S. (3 Dall.) at 276 . Madison in the Continental Congress explained that "a repeal of those contravening laws was expedient, and even necessary, to free the courts from the bias of their oaths, which bound the judges more strongly to the states than to the federal authority." JAMES MAIISON, DEBATES IN THE CONGRESS OF THE CONFEDERATION (Mar. 21, 1787), reprinted in 5 DEBATES ON THE ADOPTION OF TIIE FEderal Constitution 98-99 (J. Elliott n.d.) (2d ed. 1968) [hereinafter ElluotT's Debates]. 'This amounts to a concession that despite the resolution (at least many) state courts would not regard treaties as laws binding on them. As both Iredell and Story observed, the Supremacy Clause was adopted to "obviate this difficulty." Ware, 3 U.S. (3 Dall.) at 277; 3 STORY, supra note 12, at 696.

${ }^{18}$ See Iredell's opinion in Ware, 3 U.S. (3 Dall.) at 277; 3 STORY, supra note 12, at 696. In the Continental Congress, Yates at first objected to the portion of the resolution declaring treaties to be the law of the land, noting that "the states, or at least his state, did not admit it to be such until clothed with a legal sanction." MADISON, supra note 17 (Mar. 20, 1787), reprinted in 5 ELLIOTT's DEBATEs 98. On the next day, however, he declared himself "satisfied with the resolutions as they stood" because "the words 'constitutionally made" ... qualify sufficiently the doctrine on which the resolution was founded." Id. 
it declared treaties to be "the supreme Law of the Land" and directed the courts to give them effect without awaiting action by the legislatures of either the states or the federal Government. It effectuated a wholesale incorporation of U.S. treaties into domestic law, dispensing with the need for retail transformation of treaties into domestic law by Congress. ${ }^{19}$

The history of the Supremacy Clause thus shows that its purpose was to avert violations of treaties attributable to the United States, and that the Founders sought to accomplish this goal by making treaties enforceable in the courts at the behest of affected individuals without the need for additional legislative action, either state or federal ${ }^{20}$ The clause's allocation-of-powers function was cogently summarized by Justice Story in his Commentaries on the Constitution of the United States. Story noted the "notorious" history of "gross[ ] disregard[ ]" of treaties by the states, which considered treaties "not as laws, but like requisitions, of mere moral obligation, and dependent upon the good will of the states for their execution." "2l Observing that the Supremacy Clause had been inserted in the Constitution to "obviate this difficulty," 22 Story wrote as follows:

It is ... indispensable that [treaties] should have the obligation and force of a law, that they may be executed by the judicial power, and be obeyed like other laws.... The difference between considering them as laws, and considering them as executory, or executed contracts, is exceedingly important in the actual administration of public justice. If they are supreme laws, courts of justice will enforce them directly in all cases, to which they can be judicially applied. ... If they are deemed but solemn compacts, promissory in their nature and obligation, courts of justice may be embarrassed in enforcing them, and may be compelled to leave the redress to be administered through other departments of the government. ${ }^{23}$

The recognition that treaties, along with the Constitution and federal statutes, are "law" and therefore enforceable by the courts without prior legislative transformation into domestic law does not, of course, mean that treaties may be enforced in court by any individual at any time. The effect of the Supremacy Clause was to superimpose the

\footnotetext{
" See generally Vázquez, supra note 2, at 1097-1104; Carlos Manuel Vázquez, The "Self-Executing" Character of the Refugee Protocol's Nonrefoulement Obligation, 7 Geo. ImMIGR. L.J. 39, 44-49 (1993). See also Paust, supra note 1 , at $760-63$.

"Because the lower federal courts derive their jurisdiction entirely from federal statutes-because, in other words, the Article III jurisdiction of the lower federal courts is not "self-executing" — no treaty may be enforced in these courts without some authorizing legislation. The statement that the Supremacy Clause makes treaties enforceable in court without additional legislative authorization is therefore technically true only with respect to state courts and the U.S. Supreme Court (whose Article III jurisdiction is self-executing). (The same may be said about the Constitution and statutes, for that matter.) Indeed, because state courts, too, exist and possess jurisdiction only pursuant to state law, it might be contended that, even here, treaties are enforceable in court only if supplemented by other laws. (Again, to the extent this contention is true, it applies equally to federal statutes and the Constitution itself.) This observation merely illustrates that no law is wholly "selfexecuting." Recognizing that every law requires some legislative supplementation, in turn, means that the first question that must be addressed whenever a treaty (or any law) is claimed to be non-self-executing should be: what is it that the treaty assertedly fails to accomplish itself? (The next question should be: does some other law accomplish it?) As described in the text, the Supremacy Clause eliminated the need for one form of legislative supplementation: it dispensed with the need for legislation giving the treaty provision the force of domestic law and thus making the treaty cognizable by (and binding on) courts and other domestic-lawapplying officials. The Supremacy Clause (itself a law) may be said to "execute" all treaties in this respect.

Taking the foregoing objections into account, the statement in the text may be qualified as follows: the Supremacy Clause makes treaties "directly" enforceable in courts that exist and possess jurisdiction over the subject matter, at the behest of individuals who have standing and, if necessary, a right of action. Some of these qualifications are discussed in the remainder of this part and in part $V$ infra. Additional qualifications are no doubt necessary.

3 STORX, supra note 12 , at 696 .

II. Id.

Id. at 695.
} 
nation's treaty obligations, as well as the Constitution and federal statutes, on the existing corpus juris of the states as supreme federal law. By virtue of the Supremacy Clause, treaties of their own force nullify inconsistent state laws and earlier federal laws, and the judicial mechanisms available generally to enforce laws in the United States are available to enforce treaties. ${ }^{24}$ The Supremacy Clause does not eliminate every possible obstacle a litigant relying on a treaty might face, but it does eliminate one: without the clause, the nation's treaties would merely have possessed the status of international law enforceable only by states and only in international fora; the Supremacy Clause gives treaties the character of municipal law enforceable in domestic courts at the behest of private individuals. ${ }^{25}$

\section{The “INTENT-BASED" Doctrine}

\section{Foster v. Neilson and the Distinction between Self-Executing and Non-Self-Executing Treaties}

The distinction between self-executing and non-self-executing treaties was introduced into U.S. jurisprudence by the Supreme Court in Foster $v$. Neilson. ${ }^{26}$ Foster was an action in the nature of ejectment in which the plaintiffs claimed title to a tract of land in West Florida on the basis of a grant from Spain. The treaty by which sovereignty over the territory that included the disputed land was transferred to the United States ${ }^{27}$ provided, according to the English text, that the Spanish grants "shall be ratified and confirmed to the parties in possession thereof." The plaintiffs argued that their title to the property had been confirmed by the treaty and that the court therefore was required to recognize their title in the land. The Supreme Court decided that the courts could not recognize the Spanish grant as valid for purposes of domestic law until Congress enacted legislation confirming the grants.

The Court began its discussion of the self-execution issue by describing; the effect of treaties in countries that do not have a Supremacy Clause:

A treaty is in its nature a contract between two nations, not a legislative act. It does not generally effect, of itself, the object to be accomplished, especially so far as its operation is infra-territorial; but is carried into execution by the sovereign power of the respective parties to the instrument. ${ }^{28}$

The Court, however, went on to say:

In the United States a different principle is established. Our constitution declares a treaty to be the law of the land. It is, consequently, to be regarded in courts of justice as equivalent to an act of the legislature, whenever it operates of itself without the aid of any legislative provision. ${ }^{29}$

\footnotetext{
${ }^{24}$ See generally infra part V.

${ }^{25}$ See generally Vázquez, supra note 2. See also United States v. Alvarez-Machain, 504 U.S. 655, 667 (1992) ("The Extradition Treaty has the force of law, and if, as respondent asserts, it is self-executing, it would appear that a court must enforce it on behalf of an individual regardless of the offensiveness of the practice of one nation to the other nation."); United States v. Puentes, 50 F.3d 1567, 1575 (11th Cir. 1995) (same).

26 U.S. (2 Pet.) 253 (1829).

${ }^{27}$ The Foster self-execution holding was an alternative ground for denying relief. Sce infra note 35 . Before reaching the self-execution issue, the Court held that the treaty was inapplicable because the United States possessed sovereignty over the relevant land at the time the treaty was concluded. Because the Court's conclusion that the treaty was not self-executing was an independent basis for denying relief, our discussion of the Court's self-execution holding may assume that Spain did possess sovereignty over the relevant land at the relevant time.

${ }^{28} 27$ U.S. (2 Pet.) at 314.

${ }^{2 x}$ Id. (emphasis added).
} 
The Court thus recognized that the Supremacy Clause served to alter the British rule, and established the "different principle" in the United States that treaties do not generally require legislative implementation. But the Court qualified its statement about the Supremacy Clause's effect: it said only that treaties that "operate of themselves" are applicable by the courts without legislative implementation. The Court's qualification is the source of the distinction between self-executing and non-self-executing treaties.

Given the Court's earlier observation that, in the absence of the Supremacy Clause, treaties "in [their] nature" do not operate of themselves as domestic law, its suggestion that, under the Supremacy Clause, only treaties that "operate of themselves" may be enforced by the courts as law is confusing. Interpreted broadly, the qualification threatens to resurrect the British rule, under which no treaty is "self-executing," and certain courts and commentators have seemingly so interpreted it. ${ }^{30}$ But an examination of the Court's application of the distinction to the treaty before it in Foster and in United States $v$. Percheman, ${ }^{31}$ a later case involving the same treaty, shows that the category of non-selfexecuting treaties that the Court carved out in those decisions was considerably narrower in scope.

The Court in Foster regarded the question whether the treaty operated of itself to be a matter of treaty construction. The Court focused on the words of the treaty. It said that, if the treaty had provided that the grants were "hereby" confirmed, it would have served to confirm the grants. ${ }^{32}$ But it interpreted the treaty's English text (providing that the grants "shall be ratified and confirmed") as contemplating a future act of ratification by the United States. The treaty "pledged the faith of the United States to pass acts which shall ratify and confirm the grants." and must be "executed" by the legislature before it may be applied by the courts. In the Percheman case, the Court was presented with the Spanish text of the treaty, which was equally authoritative, and which provided that the grants "shall remain ratified and confirmed." The Court reversed itself and held that the treaty did "operate of itself" and could accordingly be applied by the courts without prior legislative action. In the Court's words, the Spanish text showed that the treaty did not, as it had previously held, "stipulate for some future legislative act."34

The category of "non-self-executing" treaty that the Court recognized in Foster thus consists of treaties that do not themselves purport to affect the rights and liabilities of individuals before the court, but instead contemplate that those rights and liabilities will

\footnotetext{
"For example, Judge Bork, in his concurring opinion in Tel-Oren v. Libyan Arab Republic, 726 F.2d 774, 808 (D.C. Cir, 1984), cited Foster for the proposition that " [ $\mathrm{t}$ ] reaties of the United States ... do not generally create rights that are privately enforceable in courts." In recent litigation, the executive branch has argued that this opinion and others establish a "presumption" that treaties are not self-executing. See Vázquez, supra note 19 , at $54 \mathrm{n} .66$ (citing government submissions taking this position). For the reasons set forth in this part, Foster actually establishes the opposite presumption. The lower-court decisions on which the executive branch has relied to support its argument that there is a presumption against judicial enforceability may be interpreted instead merely to be making the factual statement that most treaties are not self-executing. See, in addition to Judge Bork's opinion in Tel-Oren, Dreyfus v. Von Finck, 534 F.2d 24, 29 (2d Cir.), cert. denied, 429 U.S. 835 (1976); Canadian Transport Co. v. United States, 663 F.2d 1081, 1092 (D.C. Cir. 1980); Mannington Mills, Inc. v. Congoleum Corp., 595 F.2d 1287, 1298 (3d Cir. 1979). So interpreted, the statement may or may not be correct as an empirical matter, but it tells us nothing about how to determine whether a given treaty is or is not self-executing. If the lower courts did mean to suggest that there is a presumption that U.S. treaties are not selfexecuting, their dicta to this effect must be rejected for the reasons set forth in this part. See also RF.STATEMENT (THIRD) OF THE FOREIGN RELATIONS LAW OF THE United STATES $\$ 111$ reporters' note 5 (1987) [hereinafter RESTATEMENT (THIRD)]; Paust, supra note 1, at 774-75.

" 32 U.S. (7 Pet.) 51 (1833).

27 U.S. (2 Pet.) at 314.

"Id. (emphasis added).

32 U.S. (7 Pet.) at $88-89$.
} 
be affected by future acts of domestic lawmaking. ${ }^{35}$ The Court's holding in Foster recognizes that the general rule established by the Supremacy Clause, under which treaties are enforceable in the courts without prior legislative action, is one that may be altered by the parties to the treaty through the treaty itself. Treaties do not require legislative implementation in the United States "by [their] nature," but they may require legislative implementation through affirmative agreement of the parties. If the parties to the treaty agreed that the rights and liabilities of the individuals before the court were to be affected only through future lawmaking acts of the states parties-if they "stipulate[d] for some future legislative act" - then the treaty does not "operate of itself" and accordingly cannot be enforced by the courts without prior legislation. ${ }^{36}$ Because such treaties

\footnotetext{
${ }^{35}$ Professor Buergenthal has argued that the decision in Foster did not in fact turn on whether the parties to the treaty had intended to require a future legislative act. He interprets the decision as reflecting instead the Court's deference to the position of the political branches that Spain had not at the relevant, time possessed sovereignty over the disputed territory. See Buergenthal, supra note 7, at 374-75. This reading of Foster, however, fails to take account of the fact that the "self-execution" holding in Fosterwas one of two independent grounds for denying relief, and that the Court deferred to the political branches only in the portion of the opinion that related to the other ground. Before holding that it was not self-executing, the Court held (by a divided vote) that the 1819 treaty between Spain and the United States was inapplicable. By the second article of that treaty, Spain ceded to the United States "all the territories which belong to [it]" in West Florida, and by the eighth article the United States agreed (according to the English text) that "all the grants ol" land made ... by his catholic majesty ... in the said territories ceded by his majesty to the United Slates, shall be ratified and confirmed." The Court in Foster concluded that the land at issue was not situated in territory that belonged to Spain in 1819, and that, accordingly, the Spanish grant did not come within the purview of Article 8. It was only after reaching this conclusion that the Court went on to hold that, even if the territory had belonged to Spain at the relevant time, Article 8 was unavailing to the plaintiffs because it was not self-executing. 27 U.S. (2 Pet.) at 310, 314 (emphasis added). In reaching the first holding, the Court deferred to the Executive's construction of an 1803 treaty between France and Spain. Id. at 309. (As the Executive construed this treaty, Spain had ceded the relevant land to France in 1803, and France had ceded it to the United States by treaty in 1804. The land was accordingly not Spain's to cede in 1819. It is noteworthy that the Court here deferred to the Executive's construction of a treaty to which the United States was not a party, and that accordingly was not the "law of the land." Foster thus cannot be read as a precedent for the proposition shat U.S. courts must defer to the Executive's construction of treaties that are the "law of the land,") The Court s self-execution holding did not in any way rest on judicial deference to the Executive's interpretation of the 1819 treaty. Indeed, the Court did not even mention any evidence of the political branches' construction of the 1819 treaty (aside from its text). That the political branches' position was not conclusive of the self-execution issue, or even significant, is strongly suggested by the holding in Percheman, in which the Court rejected the Justice Department's construction of the treaty. It is true that Percheman involved land in territory over which Spain had previously had undisputed sovereignty, but that fact did not play a role in the Court's self-execution analysis. Later, in Garcia v. Lee, 37 U.S. (12 Pet.) 511 (1838), a case involving land in the disputed territory, the Court recognized that Percheman had "overruled" Foster on the self-execution issue, and it did not purport to disturb Percheman on that score. Instead, it reaffirmed Foster's alternative holding that Auticle 8 did not apply because the relevant land did not belong to Spain in 1819. Id. at 519-20, 522. I therefore do not agree with Professor Buergenthal's suggestion, Buergenthal, supra, at $375 \mathrm{n} .209$, that Garcia confirms his interpretation of the self-execution holdings of Foster and Percheman.

${ }^{36}$ If Foster and Percheman are so interpreted, they establish that under U.S. law there is a presumption that treaties require no legislative implementation. Admittedly, there is language in Foster that does not suggest such a presumption. For example, the Court said that the pertinent question in its view was: "Dlo [the treaty's] words act directly on the grants, so as to give validity to those not otherwise valid; or do they pledge the faith of the United States to pass acts which shall ratify and confirm them?" 27 U.S. (2 Pet.) at 314 . This language suggests a "purer" interpretive enterprise than the one suggested in this article's interpretation of Foster, one uninfluenced by any presumption. A "no presumption" rule, however, would be in tension with the Court's recognition in the same case that, (1) for nations without a supremacy clause (which at that time meant all nations except the United States, see infra note 43), treaties "by [their] nature," whatever their words, could not "act directly on the grants" but instead "pledged the faith" of the parties to enact legi:lation; and (2) the Supremacy Clause established a "different principle" in the United States. As I argue bulow, the Court in Foster took insufficient account of the implications of these propositions. (Moreover, because nations negotiating treaties do not typically address matters of domestic enforcement, see text at and note 63 infra, the absence of a presumption of self-execution is, as a practical matter, tantamount to a presumplion against selfexecution.) The Court's about-face in Percheman should be interpreted as resolving the ambiguity of the Foster decision in favor of the "different principle" interpretation of the Supremacy Clause, an interpretation that, for the reasons set forth in the text, entails a presumption of self-execution.
} 
are not cognizable in the courts, it is often said that non-self-executing treaties do not have the force of domestic law. ${ }^{37}$

Although the Court in Foster suggested that it was doing no more than giving effect to the intent of the parties to the treaty, the opinion in fact disguises an important separation-of-powers holding. The Court's conclusion that the "principle" established by the Supremacy Clause is alterable through an affirmative stipulation in the treaty was not a necessary one. As noted above, in Great Britain treaties require implementing legislation regardless of the treaty's terms or the intent of the parties. In Foster the Court could have held that the "different principle" established by the Supremacy Clause is similarly unalterable by the parties to the treaty. ${ }^{38}$ The Court held instead that the parties may alter the rule by entering into a treaty that itself envisions that rights and liabilities of individuals will be affected through subsequent acts of domestic lawmaking. ${ }^{39}$

The Foster holding is easier to describe than to apply. There is little difficulty if the parties have specifically considered and come to an agreement on whether the United States' obligations are obligations to accomplish certain ends through future acts of Congress. But the Court in Foster did not seem to require evidence that the parties had addressed the problem at that level of specificity. Instead, the Court inferred such an intent from the treaty's use of the future tense ${ }^{40}$ and of language that the Court construed as contemplating the "perform[ance] of a particular act" (i.e., an "act" of legislation). 41

\footnotetext{
17 See, e.g., J. W. Peltason, Corwin and Peltason's Understanding the Constrtution 102-03 (6th ed. 1973); Louis HENKIN, ForEIGN AFFaIRs AND THE CONSTITUTION 157 (1972); Geoffrey R. Watson, The Death of Treaty, 55 OHio ST. L.J. 781, 831 (1994); Jackson, supra note 2, at 145-46; Alona E. Evans, Some Aspects of the Problem of Self-Executing Treaties, 45 ASIL PROC. 66, 68 (1951). Compare Trans World Airlines v. Franklin Mint Corp., 466 U.S. 243, 252 (1984) (because "the Convention is a selfexecuting treaty," "no domestic legislation is required to give [it] the force of law in the United States") with United States v. Alvarez-Machain, 504 U.S. 655,667 (1992) (suggesting that a treaty's self-executing character and its status as "law of the land" are separate questions). The contention that a treaty that is not self-executing lacks domestic legal force underscores the tension between the doctrine of self-executing treaties and the Supremacy Clause, which declares "all" treaties of the United States to be the "Law of the Land." Whether the contention is sound is beyond the scope of this article. I address it in a work in progress, tentatively titled Treaties as Law of the Land.

${ }^{17}$ Such an interpretation would have made the Supremacy Clause more efficacious in advancing its purpose of averting treaty violations attributable to the United States and would have obviated the doctrinal problems that the courts have encountered in drawing the distinction contemplated in Foster, see infra part II, " "IntentBased 'Non-Self-Execution in the Lower Courts," while leaving open the possibility of denying judicial enforcement on "justiciability" grounds, see infra part III. As discussed infra note 91, the conclusion that the treaty involved in Foster (as there interpreted) was not judicially enforceable could have been framed in "justiciability" rather than "intent" terms.

"Although in 1829 the Court might easily and defensibly have held that the parties lack the power to alter the constitutional default rule, such a holding would be difficult to square with subsequently developed constitutional doctrine. Under the last-in-time rule, for example, see text at and notes 8-9 supra, a later treaty must be enforced by the courts in preference to an earlier conflicting treaty, even if enforcing the later treaty would produce a violation of the earlier treaty. If the courts' ability to enforce a treaty may be altered or taken away completely by the treaty makers' subsequent agreement with the same or a different nation, it is difficult to contend that the courts' ability to enforce a treaty may not be altered or taken away by the treaty makers' concurrent agreement with a treaty partner. This point is developed in Vázquez, supra note 37.

"Later courts have interpreted Foster as establishing that "words of futurity" indicate that a treaty provision is not self-executing. See Robertson v. General Elec. Co., 32 F.2d 495, 500 (4th Cir.), cert. denied, 280 U.S. 571 (1929).

" Foster, 27 U.S. (2 Pet.) at 314. Although this language from Foster might be read to suggest that the distinction the Court had in mind was between treaty provisions establishing obligations to act affirmatively and provisions establishing obligations not to act, the Fosterand Percheman decisions show both the unworkability and the irrelevance of such a distinction. The "particular act" that the Court in Foster thought the parties had agreed to perform was an act of legislation ratifying and confirming the Spanish grants. The statement that a treaty requires legislation when its terms reflect an engagement to perform a particular act thus means only that a treaty requires legislation when its terms reflect an engagement to enact legislation. Nor did anything in either Foster or Percheman turn on whether the ultimate objective of the treaty was "affirmative" or "negative." It would have been equally plausible to characterize the ultimate objective of the relevant treaty (recognition of the validity of the grants) as "affirmative" (i.e., the obligation of everyone [including federal and state judges] to recognize the plaintiffs' ownership of the land in question) or "negative" (i.e., the obligation of
} 
But inferring an intent to require legislation in the absence of unambiguous language to that effect is a hazardous enterprise, given the multiplicity of national constitutional rules regarding the domestic effect of treaties. ${ }^{42}$ As noted above, for some nalions treaties always require implementing legislation. ${ }^{43}$ It is thus possible that the language chosen by the parties simply reflects the possibility that the treaty will require implementing legislation for certain parties no matter what the parties intended. ${ }^{44}$ Under the Supremacy Clause, however, a treaty can be "self-executing" in the United States even if it is "non-self-executing" for other nations by virtue of their constitutions. ${ }^{45}$ 'The Court's recognition that most nations at the time considered treaties to be non-self-executing "by [their] nature" should have led the Court to require more probative evidence that the parties had agreed to alter the "different principle" established for the United States by the Supremacy Clause. The Court's reversal of its Foster holding in Percheman, and its statement in the latter case that a treaty is self-executing if it "stipulates for [a] future legislative act," is probably best understood as a recognition that the stanclard applied in Foster took inadequate account of the Founders' establishment of a "different principle" in the United States. Percheman, in other words, should be interpreted to require a clear statement-a stipulation-of the parties' intent to alter the principle that, whatever the case might be for other states parties, implementing legislation is not required to make the treaty cognizable by the courts of the United States.

\section{"Intent-Based" Non-SelfExecution in the Lower Courts}

Courts and commentators seem to agree that a treaty's self-executing character is largely, if not entirely, a matter of intent. ${ }^{46}$ They are divided, however, on three important

everyone not to interfere with the plaintiffs' quiet enjoyment of the land in question). Yet the Court in neither case attempted to draw such a line. Instead, the difference in result was attributable to the difference between language suggesting the need for legislation ("shall ratify") and language suggesting no need for legislation ("shall remain ratified"). In short, what is relevant is not whether the underlying objective of the treaty is an affirmative or negative one, but whether the parties agreed to accomplish that objective through intervening acts of domestic lawmaking. Thus, even a treaty provision whose ultimate objective is essentially negative (such as the obligation not to return a refugee to a place of persecution) would be non-self-executing in the Foster sense if the parties to the treaty had stipulated that the prohibition would take effect infraterritorially (i.c., would bind domestic-law-applying officials, such as domestic courts) only upon the enactment of domestic legislation. See Vázquez, supra note 19, at 56-57 (acknowledging this possibility).

${ }_{42}$ On the diversity of constitutional approaches to domestic enforcement of treaties, see Antonio Cassese, Modern Constitutions and International Law, 192 RecueIL DEs CouRs 331 (1985 III); Eric Stein, International Law in Internal Law: Toward Internationalization of Central-Eastern European Constitutions?, 88 AJIL 4:27 (1994).

${ }^{43}$ See supra text at and notes $11-12$. See also Polites v. The Commonwealth, 70 C.L.R. 60 (1945) (Austl.). Justice Iredell stated in Ware v. Hylton, 3 U.S. (3 Dall.) 256, 272 (1796), that the United States Constitution "affords the first instance of any government ... saying, treaties should be the supreme law of the land."

${ }^{44}$ As discussed below, disentangling a treaty's self-executing or non-self-executing character as a matter of U.S. law (which, under Foster, turns on the intent of the parties) from its self-executing or non-self-executing character as a matter of the various other parties' domestic constitutional rules is tricky and has proven to be a significant source of confusion among the lower courts.

${ }_{45}$ This was established as early as 1796 , when the Court decided Ware v. Hylton. Because, as Justice Iredell recognized, treaties never have domestic effect in Great Britain, there could have been no common intent of the parties that the treaty be binding on courts without implementing legislation. The Court held, however, that the Supremacy Clause nevertheless made the treaty binding on courts in the United States.

${ }^{46}$ See, e.g., Goldstar (Panama), S.A. v. United States, 967 F.2d 965, 968 (4th Cir.), cert. denied, 113 S.Ct. 411 (1992); Frolova v. Union of Soviet Socialist Republics, 761 F.2d 370, 373 (7th Cir. 1985); Cardenas v. Smith, 733 F.2d 909, 918 (D.C. Cir. 1984); Tel-Oren v. Libyan Arab Republic, 726 F.2d 774, 778 (D.C. Cir. 1984) (Edwards, J., concurring); British Caledonian Airways v. Bond, 665 F.2d 1153, 1160 (D.C. Cir. 1981); United States v. Postal, 589 F.2d 862, 876, 874 (5th Cir. 1979); Diggs v. Richardson, 555 F.2d 848, 851 (D.C. Cir. 1976); Linder v. Calero Portocarrero, 747 F.Supp. 1452, 1463 (S.D. Fla. 1990), affd in part and rev'd in part, 963 F.2d 332 (1992). As I show in part III, however, in many cases "intent" does not do the work that the courts claim it does. 
questions: Whose intent counts? What must the relevant persons have intended? And how is the intent to be gleaned?

Foster and Percheman supplied answers to all three questions. The Court in those cases sought to determine the intent of the parties to the treaty, as expressed in its text, concerning whether they wished to alter the principle that treaties in the United States may be enforced by the courts without prior legislative action. Lower courts in recent years, however, have sought to discern the intent not of the parties to the treaty, but of the U.S. negotiators of the treaty, the President in transmitting it to the Senate for its advice and consent, and the Senate in giving its advice and consent. ${ }^{47}$ Moreover, in their efforts to discern such intent, they have gone beyond the treaty's terms, relying instead on statements in the negotiating history and statements made during the advice-andconsent process. ${ }^{48}$ Finally, a few courts have looked not for an intent to alter the rule that treaties do not generally require legislative implementation to be enforceable by the courts of this country, but for an intent that the treaty be enforceable in the courts, and, in the absence of evidence of such an intent, they have held that the relevant treaty" is not "self-executing" and thus not enforceable by the courts of this country. ${ }^{49}$

The increasing willingness of some courts to go beyond the words of the relevant treaty provision and to rely on negotiating history and statements made during the advice-and-consent process in determining whether a treaty is self-executing corresponds to a more general shift by the courts in their methodology for interpreting treaty provisions. To the extent the courts look to these sources to discover the intent of the parties to the treaty, the shift in methodology is subject to the same criticisms that have been directed at the practice more generally in the context of interpreting treaties, and, more generally still, in the context of interpreting legal texts. This change in methodology will not be examined further in this article. ${ }^{50}$

Whose intent? To the extent the courts have begun to perceive the inquiry not as a search for the intent of the parties but, rather, as a search for the unilateral ${ }^{51}$ intent of the President in ratifying the treaty, or of the Senate in giving its advice and consent, or even of lower-level executive officials, the shift warrants further consideration. As noted, the Court in Foster and Percheman relied on the treaty's terms, which reflect the intent of the parties to the treaty, not just that of the United States. These cases establish that the "different principle" established by the Supremacy Clause is one that may be altered by the parties to the treaty. The Court did not go so far as to hold that the principle embodied in the Supremacy Clause could be altered by the unilateral action of the U.S. treaty makers (the President and two-thirds of the Senators), let alone

\footnotetext{
${ }^{17}$ See, e.g., Frolovia, 761 F.2d at 376 (relying on preratification statement of President); Islamic Republic of Iran v. Boeing Co., 771 F.2d 1279, 1284 (9th Cir. 1985) (same), cert. dismissed, 479 U.S. 957 (1986); Postal, 589 F 2d at 881-83 (relying on preratification statements of State Department officials and U.S. negotiators); Edwards v. Carter, 580 F.2d 1055, 1057 n.4 (D.C. Cir.) (relying on preratification statements by Attorney General and State Department Legal Adviser), cert. denied, 436 U.S. 907 (1978); Diggs, 555 F.2d at 851 n.11 (relying on State Department's silence); In re Stoffregen, 6 F.2d 943 (D.C. Cir.) (relying on postratification position of U.S. Patent Office and postratification views of Congress), cert. denied, 269 U.S. 569 (1925); Ortman v. Stanray Corp., 371 F.2d 154, 157 (7th Cir. 1967) (relying on postratification statement of Attorney General); Rousseau v. Brown, 21 App. D.C. 73, 76 (D.C. 1903) (relying on postratification position of U.S. Patent Office). See also Cook v. United States, 288 U.S. 102, 119 n.19 (1932) (relying on preratification statement of Secretary of State and postratification "administrative practice" of the Treasury Department and Coast Guard); Cameron Septic Tank Co. v. Knoxville, 227 U.S. 39, 49 (1913) (relying on apparent views of subsequent Congress).

See cases cited supra note 47.

"See Postal, 589 F.2d 862.

"On this question, see, e.g, United States v. Stuart, 489 U.S. 353, 371-77 (1989) (Scalia, J., concurring). See generally David J. Bederman, Revivalist Canons and Treaty Interpretation, 41 UCLA L. REv. 953 (1994); Detlev F. Vagts, Trealy Interpretation and the New American Ways of Law Reading, 4 EuR. J. INT'L L. 472 (1993).

"By "unilateral" I mean not (necessarily) shared (or agreed to) by the other parties to the treaty.
} 
by lesser combinations of these officials or their agents involved in negotiating, advising or consenting to, or ratifying the treaty. The courts that have looked at the "intent" of such officials not just as evidence of the intent of the parties, but as having independent significance for the self-execution question, have modified the nature of the selfexecution inquiry in a significant way.

This modification of the self-execution doctrine is problematic given the apparent purposes of the Supremacy Clause. The clause was made applicable to treaties to avert conflicts with other nations that could be expected to result from violations of treaties attributable to the United States. ${ }^{52}$ The Founders sought to achieve this goal by declaring all treaties to be "Law of the Land" and thus enforceable in the courts once they became binding internationally, without the need for action by an additional body (the House). The Court's recognition in Foster of a category of treaty that is not enforctable in the courts without prior legislative action was somewhat in tension with the purposes of the Supremacy Clause because it made the enforcement of some treaties by the courts dependent on action by the legislature. If the House failed to agree to the requisite legislation, the treaty would be violated and international friction could result. But the Foster exception is less problematic from the standpoint of the Supremacy Clause than the recent expansion of the exception by some lower courts. If all parties to the treaty affirmatively agreed that the ultimate object would be achieved by the United States through future acts of domestic lawmaking, then any international friction that might result from Congress's failure to enact the required legislation could be expected to be less severe because the parties were at least on notice that congressional action was required. The parties may be said to have "assumed the risk" that Congress might fail to carry out its obligations. Although this "assumption of risk" theory would not diminish the United States' responsibility to other parties under international law, it might defensibly have been relied on in Foster to support a domestic constitutional rule concerning the allocation of enforcement responsibility as between the courts and Congress. But if the courts' power to enforce the treaty could be altered through the unilateral action of U.S. officials, the resulting international friction would not be tempered in the same way. Permitting the "different principle" established in the Supremacy Clause to be altered through the unilateral acts of U.S. officials is a greater inroad on the clause's purposes, and thus requires an extension of the "intent-based" category of non-selfexecuting treaty beyond what was recognized in Foster and Percheman.

In recent years, the U.S. treaty makers have arguably ${ }^{53}$ been purporting to exercise a power unilaterally to alter the principle embodied in the Supremacy Clause. Upon ratifying recent treaties, they have expressed their intent on the self-execution question through "declarations" that the treaties are not self-executing. ${ }^{5.4}$ These declarations have been attached to treaties that would clearly not otherwise be wholly non-self-executing. ${ }^{55}$

\footnotetext{
522 See Vázquez, supra note 2, at 1103. See also 3 STORY, supra note 12, at 694 ("“[U]nless [treaties] are scrupulously obeyed, and enforced, no foreign nation would consent to negotiate with us; or if it did, any want of strict fidelity on our part in the discharge of the treaty stipulations would be visited with reprisals, or war.").

${ }_{53}^{53}$ See infra note 56.

${ }^{5}$ Such a declaration was attached to the Convention against Torture and Other Cruel, Inhuman or Degrading Treatment or Punishment, GA Res. 39/46, Dec. 10, 1984, Hein's No. Kav 2398. The U.S. declaration is discussed in S. EXEC. REP. No. 30, 101st Cong., 2d Sess. 12 (1990). A similar declaration was attached to the Covenant on Civil and Political Rights and the International Convention on the Elimination of All Forms of Racial Discrimination. See Louis Henkin, U.S. Ratification of Human Rights Conventions: The Cihost of Senator Bricker, 89 AJIL 341, 348 (1995).

${ }_{55}^{55}$ For example, Article 3 of the Torture Convention prohibits parties from extraditing persons to places in which they are likely to be tortured. In the absence of a declaration purporting to place the issue beyond the courts' cognizance, such a provision would undoubtedly be enforceable by courts entertaining habeas corpus petitions of persons subject to extradition orders. See Jacques Semmelman, Federal Courts, the Constitution, and
} 
If the intent of the U.S. treaty makers were dispositive of the issue, unilateral statements reflecting the views of the President and two-thirds of the Senate that the treaty is not self-executing would effectively make the treaty non-self-executing. To give effect to such statements would be to recognize that the principle established in the Supremacy Clause-the rule that treaties may be enforced in the courts without prior legislative implementation - may be altered not only by the parties to the treaty, but by the U.S. treaty makers acting unilaterally. ${ }^{56}$

The lower courts that have given independent weight to far more ambiguous statements of executive branch officials ${ }^{57}$ would presumably, a fortiori, give conclusive weight to unilateral U.S. declarations of non-self-execution. ${ }^{58}$ The conformity of this practice with the Supremacy Clause, however, has never been considered by the Supreme Court. The Restatement (Third) of the Foreign Relations Law of the United States apparently approves of the practice of giving effect to unilateral statements of U.S. officials to determine whether a treaty is self-executing. It reasons as follows:

In the absence of a special agreement, it is ordinarily for the United States to decide how it will carry out its international obligations. Accordingly, the intention of the United States determines whether an agreement is to be self-executing in the United States or should await implementation by legislation or appropriate executive or administrative action. If the international agreement is silent as to its self-executing character and the intention of the United States is unclear, account must be taken of any statement by the President in concluding the agreement or in submitting it to the Senate for consent or to the Congress as a whole for approval, and of any expression by the Senate or by Congress in dealing with the agreement. ${ }^{59}$

But the Restatement's reasoning is faulty: the second quoted sentence does not follow from the first. It may be conceded that, as far as international law is concerned, it is "for the United States to decide how it will carry out its international obligations," in

the Rule of Non-Inquiry in Intermational Extradition Proceedings, 76 CORNELL. L. Rev. 1198, 1221-26 (1991) (especially text at and nn.143,203). Such courts routinely apply treaty provisions that address whether an individual is extraditable; upon ratification, Article 3 of the Torture Convention would have become another such provision had it not been for the declarations attached to it. There is nothing about the issues that Article 3 addresses that would have made them nonjusticiable. The courts in other contexts entertain claims of torture, see Torture Victim Protection Act of 1991, Pub. L. No. 102-256, 106 Stat. 73 (1992); Filartiga v. Peña-Irala, 630 F.2d 876 (2d Cir. 1980), and make findings of fact regarding a state's propensity to persecute individuals in other ways, see, e.g., INS v. Cardoza-Fonseca, 480 U.S. 421 (1987). Thus, in the absence of the declarations attached to the Convention by the United States, Article 3 would undoubtedly have been considered judicially enforceable.

The United States also attached to the Convention a declaration stating that, in this country, the responsibility for enforcing Article 3 shall reside exclusively in the Secretary of State. This provision seems wholly redundant in light of the declaration making the entire Convention non-self-executing. It has always been recognized that the Secretary has the discretion not to extradite someone whose extradition is otherwise required by treaty if there is a danger of mistreatment by the receiving state. See generally Semmelman, supra. The nonselfexecution declaration purports to make the Secretary's decision to do so (or not to do so) unreviewable. It is not apparent what, if anything, the additional statement that the Secretary has the "exclusive" power to do so accomplishes.

"It is debatable, however, whether non-self-execution declarations that are formally communicated to the other treaty parties and are deposited with the U.S. instruments of ratification can be accurately characterized as representing only the unilateral views of the United States. See the discussion of this issue in Stefan A. Rjesenfeld \& Frederick M. Abbott, The Scope of U.S. Senate Control over the Conclusion and Operation of Treaties, 67 CHI.-KENT L. REv. 571 (1991), and in Vázquez, supra note 37.

${ }^{17}$ See cases cited supra note 47.

See Jackson, supra note 2, at 156 ("[T] he courts will apparently follow the formally expressed view" of the President and Senate concerning a treaty's non-self-executing character.).

"RESTATEMENT (THIRD), supra note 30 , $\$ 111 \mathrm{cmt}$. $h$. See also $\$ 314 \mathrm{cmt}$. $d$ ("A treaty ratified or acceded to by the United States with a statement of understanding becomes effective in domestic law ( $\$ 111)$ subject to that understanding."); $c f . \$ 303 \mathrm{cmt} d$ (listing condition "that the treaty shall not be self-executing" as example of condition Senate might attach to its consent to a treaty that is "presumably not improper"). 
the absence of an agreement in the treaty itself. This means that U.S. law determines whether a treaty will be enforceable in court without prior legislative implementation. But, as discussed above, the most pertinent U.S. law on this question is the Supremacy Clause. As interpreted in Foster, that clause allocates to the courts the duty to enforce treaties just as they enforce the Constitution and federal statutes unless the parties to the treaty stipulate otherwise. The question on the table is whether the clause also permits U.S. officials, acting without the consent of the other parties, to declare treaty provisions to be judicially unenforceable. In answering this question, the notion that "it is for the United States to determine how to carry out its international obligations" is unhelpful, as we are interpreting the provision of the U.S. Constitution by which the Framers determined how the United States would carry out its international treaty obligations. ${ }^{60}$

Whether the Supremacy Clause permits U.S. officials, acting unilaterally, to alter the "different principle" established by that clause, and, if so, which officials and under what circumstances, are questions beyond the scope of this article. I note, however, that the conformity of this practice with the Supremacy Clause has gone largely unexamined by the courts, that the Restatement $s$ defense of the practice is unpersuasive, and that, for the reasons set forth above, the practice is in some tension with the text and apparent purposes of the Supremacy Clause. ${ }^{61}$

Intent about what? Some lower courts not only have shifted the focus from the intent of the parties to the unilateral intent of U.S. officials; they also have shifted the focus of what it is that the relevant people must have formulated an intent about. Rather than looking for evidence of an affirmative intent to alter the principle that treaties in the United States do not require legislative implementation to be enforceable in the courts as law, they have looked for evidence of.an intent to make these treaties enforceable in the courts as law. They have reversed the presumption recognized by the Court in Foster and Percheman so that, in the absence of any evidence of an intent on the part of these officials, a treaty is non-self-executing and thus not enforceable in the courts without prior legislative implementation. ${ }^{62}$

\footnotetext{
${ }^{6 n}$ Nor does the truism that the greater power includes the lesser lend support to the notion that the treaty makers have the power unilaterally to make a treaty judicially unenforceable. The power not to enter into a treaty at all does not include the power to enter into a treaty but make it judicially unenforceable. If the purpose of the Supremacy Clause was to avert treaty violations by making treaties, once ratified and binding on the United States, enforceable in the courts, the Founders may well have preferred no theaty at all to a treaty that bound the nation internationally but was not judicially enforceable. Cf. 2 MAx FARRAND, TuE ReCORDS OF THE FEDERAL Convention of 1787, at 393 (rev. ed. 1966) (Gouverneur Morris was "not solicitous to multiply and facilitate Treaties. ... The more difficulty in making treaties, the more value will be set on them.").

${ }_{61}$ There is both judicial and scholarly authority that calls into question the constitutionality or effectiveness of the non-self-executing declarations that have been attached by the United States to recent treaties. Sce Henkin, supra note 54, at 346-48,349; John Quigley, The International Covenant on Civil and Political Rights and the Supremacy Clause, 42 DePAul L. Rev. 1287 (1993); Jordan J. Paust, Avoiding Fraudulent Executive Policy: Analysis of Non-Self-Execution of the Covenant on Civil and Political Rights, 42 DEPAUL L. REv. 1257 (1993); Riesenfeld \& Abbott, supra note 56; Charles H. Dearborn III, Note, The Domestic Legal Effect of Declarations That Treaty Provisions Are Not SelfExecuting, 57 TEx. L. Rev. 233 (1979); Power Auth. of N.Y. v. Federal Power Comm'n, 247 F.2d 538 (D.C. Cir.), vacated and remanded with instructions to dismiss as moot sub nom. American Pub. Power Ass'n v. Power Auth., 355 U.S. 64 (1957).

I examine this question in Vázquez, supra note 37, and find merit in two arguments favoring the constitutionality and effectiveness of these declarations: (1) the declarations are not "unilateral," but represent an agreement among the parties to the treaty and thus fall within the rule set forth in Foster (cf. supra note 56); and (2) if the U.S. treaty makers possess the constitutional power to abrogate a treaty for purposes of domestic law, even when such abrogation is not permitted by international law, they must also possess the constitutional power to enter into a treaty but unilaterally deny it domestic legal force.

${ }_{622}$ United States v. Postal, 589 F.2d 862 (5th Cir. 1979). See also cases cited supra note 30 and infra note 67. Additionally, in recent litigation the executive branch has taken the position that there is a presumption that treaties are not selfexecuting, relying (directly or indirectly) on Foster. See supra note 30. For a more extended critique of this position, see Vázquez, supra note 19, at 44-53. See also RestaTEMENT (Tiurd), supra note 30,
} 
Where the presumption is placed assumes enormous significance in this context. Perhaps because of the diversity of domestic-law rules on the subject, nations negotiating treaties rarely address matters of domestic implementation. ${ }^{63}$ The constitutional default rule will therefore ultimately determine the judicial enforceability of the vast majority of treaties. To adopt a presumption against self-execution would thus be to make most treaties non-self-executing and thus judicially unenforceable without legislative implementation.

A presumption of non-self-execution is difficult to square with the text of the Supremacy Clause. Such a presumption would establish as the general rule in the United States that treaties are not binding on the courts; they would be so binding only if the parties affirmatively stipulated that they were not subject to legislative implementation. To be sure, this interpretation would not deprive the Supremacy Clause of all effect: since, under the British rule, treaties lacked domestic legal force even if the parties wanted them to have such force, the Supremacy Clause, so interpreted, would at least have had the effect of giving the treaty makers the power to give domestic legal force to the treaties they made. This modification of the prior rule would not have been trivial, but the Supremacy Clause's terms do not easily bear a "power-conferring" construction. Article II gives the President (with the Senate's consent) the power to make treaties; the Supremacy Clause purports to make treaties, once made, binding on the courts. The courts that have suggested that treaties are judicially enforceable only if they were intended to be judicially enforceable have thus transformed the self-execution inquiry in a manner that seems fundamentally incompatible with the text of the Constitution.

Even courts that have not gone so far as to adopt a presumption of non-self-execution have nevertheless failed in their decisions to take adequate account of the fact that the contemplated effect of the Supremacy Clause was to reverse the British rule. For example, courts have considered whether treaties that include provisions phrased in the following terms are judicially enforceable before legislation is enacted: "Every country party to this Convention undertakes to adopt, in accordance with its constitution, the measures necessary to insure the application of this Convention." The U.S. Court of Appeals for the Third Circuit found that this language signified that the treaty was not considered by the parties to be self-executing. ${ }^{64}$ There are several things wrong with this conclusion. First, it is well accepted that some provisions of a treaty may be self-executing while others are not. ${ }^{65}$ Thus, even if the quoted provision suggested that some implementing legislation would be required, it is possible that the contemplated legislation relates only to some provisions of the treaty, not to all. Second, as discussed above, in some countries implementing legislation is always required, and other countries may require it in circumstances in which it would not be required in the United States. Therefore, the quoted provision may merely reflect the fact that implementing legislation may be required in

$\$ 111$ reporters' note 5 (criticizing Postal); Stefan A. Riesenfeld, The Doctrine of Self-Executing Treaties and U.S. v. Postal: Win at Any Price?, 74 AJIL 892 (1980) (same).

"See Iwasawa, supra note 1 , at 654 ("Whether or not a treaty provision will be self-executing for a particular state party ... ha[s] generally not been [a] consideration when states enter into treaty obligations.”); Paust, supra note 1, at 770-71 (the parties to a treaty "rarely concern themselves with the details of domestic implementation").

"Mannington Mills, Inc. v. Congoleum Corp., 595 F.2d 1287, 1298 (3d Cir. 1979). Other lower courts have relied on provisions such as these, or provisions that are even less probative of a "stipulation for a future legislative act," to support their conclusion that a particular treaty is not self-executing. See Postal, 589 F.2d at 876; Tel-Oren v. Libyan Arab Republic, 726 F.2d 774, 809 (D.C. Cir. 1984) (Bork, J., concurring); Linder v. Calero Portocarrero, 747 F.Supp. 1452, 1463 (S.D. Fla. 1990); Handel v. Artukovic, 601 F.Supp. 1421 (C.D. Cal. 1985); Haitian Refugee Center v. Gracey, 600 F.Supp. 1396, 1406 (D.D.C. 1985), affd on other grounds, 809 F.2d 794 (D.C. Cir. 1987).

$\therefore$ See REstatekiENT (THIRD), supra note $30, \$ 111 \mathrm{cmt} . h$ 
some countries because of their domestic constitutional rules. Our domestic constitutional rule (the Supremacy Clause) dispenses with the need for implementing legislation unless the parties (or perhaps the U.S. treaty makers) reversed the ordirary rule by "stipulat[ing] for some future legislative act." The quoted treaty provision tells us that parties must enact the domestic measures that are "necessary" to ensure the application of the Convention; it does not make legislation "necessary" if it otherwise: would not be. For this reason, such provisions should not be considered "stipulations for a future legislative act" that render a treaty non-self-executing under Foster. ${ }^{66}$

Courts and commentators in recent years have variously described the "intent" that is relevant to the self-execution inquiry as an intent to create "private rights," or "judicially enforceable" "private rights" or "private rights of action," or as an intent that the provision be "judicially enforceable at the behest of individuals." raise several concerns. First, insofar as they suggest that the absence of an intent to make the treaty judicially enforceable means that the treaty is not judicially enforceable, they invert the presumption established by the Supremacy Clause. Second, the formulations misleadingly suggest that the treaty's judicial enforceability is always a matter of intent; as shown in part III below, a treaty may be judicially unenforceable for reasons other than intent. Finally, the references to "rights" or "rights of action" or enforceability "by individuals" suggest a conflation of the judicial enforceability vel non of the treaty with the question of who has standing to enforce the treaty in court and what remedies are available to such persons. As discussed in part $\mathrm{V}$, these issues are analytically distinct. ${ }^{68}$ Even if a treaty does not confer a remedy, an otherwise justiciable treaty obligation is, by virtue of the Supremacy Clause, enforceable in court at the behest of individuals, either defensively by persons who have standing or offensively by persons who have a right of action. If a right of action is not conferred by other state or federal laws, the availability of judicial relief may depend on the treaty makers' intent to create a private right of action. ${ }^{69}$ But, as explained in part $\mathrm{V}$, the judicial enforceability vel non of a treaty does not depend on anyone's intent to create a "right of action."70

\section{The "JusticiabilitTy" DOCTRINE}

Foster established a relatively circumscribed exception to the general rule that treaties may be enforced as law by the courts without prior legislative implementation. The Court recognized that this general rule was alterable by the parties to the treaty through an affirmative stipulation in the treaty itself. As discussed, this principle has been expanded by some courts to recognize a unilateral affirmative stipulation by the U.S. treaty makers,

See Vázquez, supra note 19, at 58-59; Paust, supra note 1 , at 775 n.97.

(17 See, e.g., Goldstar (Panama), S.A. v. United States, 967 F.2d 965, 968 (4th Cir. 1992) ("intent to provide a private right of action" or to provide "a privately enforceable cause of action"); United States v. Davis, 767 F.2d 1025, 1030 n.9 (2d Cir. 1985) (intent to confer "judicially enforceable rights on individuals"); Tel-Oren, 726 F.2d at 809 (Bork, J., concurring) ("inten[t] to be judicially enforceable at the behest of individuals" and "inten [t] to give individuals the right to enforce [the treaty] in municipal court"); United States v. Noriega, 808 F.Supp. 791, 799 (S.D. Fla. 1992) ("inten[t] to impart on an individual the right to bring a legal action to force compliance with the treaty").

${ }^{63}$ The standing issue is discussed infra note 134 and in Vázquez, supra note 2, at 1133-41. The closely related right-of-action issue is discussed in part V infra, and in Vázquez, supra, at 1141-57.

${ }^{69}$ But $c f$. Vázquez, supra note 2, at 1157-61 (arguing that a right of action should be held to be implicit in a treaty in certain circumstances even if there is no evidence that the parties [or the treaty makers] affirmatively intended to create a right of action).

${ }^{70}$ The similar statement that a tr"aty is enforceable at the behest of individuals only if it creates a "private right," see, e.g., Mannington Mills, Inc. v. Congoleum Corp., 595 F.2d 1287, 1298-99 (3d Cir. 1979); Dreyfus v. Von Finck, 534 F.2d 24, 30 (2d Cir. 1976), is either wrong (if "right" is understood as a synonym for "right of action") or a tautology (if "right" is understood more broadly as the obverse of a legal duty). 
and some courts have looked beyond the words of the treaty to find such a stipulation. Some courts have even reversed the presumption and have looked not for an intent to require legislation, but for an intent to dispense with legislation. Even with the foregoing variations, the focus of the "self-execution" inquiry remains on finding evidence of an intent regarding whether the treaty may be enforced in court without prior legislative implementation.

Some lower courts in recent years, however, have perceived the inquiry not as a search for evidence of an intent regarding whether the ultimate object of the treaty was to be accomplished through future acts of legislation. Instead, they have viewed a treaty's selfexecuting or non-self-executing nature as a characteristic that exists independently of any intent to require legislation. They have perceived this characteristic as a part of the treaty's essence, to be discerned by the court using whatever guidance it finds useful. Although these courts continue to consider the intent of the parties and the U.S. treaty makers relevant, they do not limit their search to ascertaining such intent. The precise nature of their inquiry remains in many respects obscure, but it is evident that these courts have a conception of the self-executing/non-self-executing dichotomy that differs from that reflected in the Foster and Percheman decisions, as interpreted above.

A review of the decisions that ascribe independent significance to factors other than intent shows that these courts have examined under the "self-execution" rubric various concepts that are not unique to treaties. These include matters such as whether the claim is justiciable, whether the litigant has standing, and whether the litigant has a right of action. Rather than examine these issues separately as they (generally) do in constitutional and statutory cases, courts confronted with treaties have rolled all of these issues into a single "self-execution" question.

The decision in Frolova v. USSR ${ }^{71}$ illustrates this approach. The court there enumerated the following factors as relevant to whether the treaty was "intended to be selfexecuting":

(1) the language and purposes of the agreement as a whole; (2) the circumstances surrounding its execution; (3) the nature of the obligations imposed by the agreement; (4) the availability and feasibility of alternative enforcement mechanisms; (5) the implications of permitting a private right of action; and (6) the capability of the judiciary to resolve the dispute. ${ }^{72}$

Although the court said that the ultimate issue was whether the treaty was "intended" to be self-executing, the list of factors shows that the "intent" the court had in mind was a purely constructive intent (which is to say, not intent at all). The court did not search for an actual intent or even infer an intent; it imputed an intent based on the factors listed. The factors address reasons, unrelated to intent, why the treaty obligation should perhaps not be judicially enforceable; they relate to whether the obligation is a justiciable one or whether the plaintiff has a right of action. These are distinct issues that, outside the treaty context, are examined by the courts separately. In treaty cases, however, as Frolova shows, these issues are all thought to be part of a single "selfexecution" inquiry.

This section examines some of the factors other than intent that some courts have considered in determining whether particular treaties are self-executing, and thus judicially enforceable without additional legislation by Congress. This discussion will show that the self-executing/non-self-executing distinction has come to serve the functions

\footnotetext{
"Frolora v. Union of Soviet Socialist Republics, 761 F.2d 370, 373-76 (7th Cir. 1985).

$\because$ Id. at 373 .
} 
that are served in the statutory and constitutional contexts by the concepts of justiciability and "political question."

\section{Precatoriness and Non-Self-Execution}

Like other laws, treaties are enforceable in the courts only if they impose obligations. Some treaties do not impose obligations but, instead, set forth aspirations. The courts have found that such treaties are not judicially enforceable, and in the process they have described these treaties as "non-self-executing."73 That "precatory" treaties are not judicially enforceable is neither surprising nor troubling. The role of the courts in our governmental system is to enforce the rights of individuals. ${ }^{74}$ If a treaty doe:s not impose an obligation on the defendant to treat the plaintiff in a given way, it does not give the plaintiff a correlative right to be so treated. Litigants arguing that the treaty entitles them to such treatment should therefore lose on the merits. That "precatory" provisions are not judicially enforceable does not distinguish treaties from statutory or constitutional provisions. $^{75}$

Of course, the line that separates "precatory" provisions from provisions that impose "obligations" may not always be bright. Where the line is drawn is a matter of domestic law that effectively allocates enforcement power (and responsibility) between the courts and the legislature. In the context of federal statutes addressed to state governments, a body of case law has arisen to distinguish "obligatory" provisions enforceable by the courts from "precatory" provisions whose "enforcement" is allocated to the other branches of the federal government. ${ }^{76}$ With respect to treaties, the self-executing/nonself-executing distinction has been equated by some courts with the obligatory/precatory distinction and has similarly served to allocate enforcement responsibility between the courts and the political branches.

Recognition of this category of non-self-executing treaty expands the notion of a "nonself-executing" treaty beyond what was recognized in Foster and Percheman. "Precatory" treaty provisions are deemed judicially unenforceable not because of the parties' (or anyone's) intent, but because what the parties agreed to do is considered, in our system of separated powers, a "political" task not for the courts to perform. ${ }^{77}$ The parties'

\footnotetext{
${ }^{73}$ In INS v. Stevic, 467 U.S. 407,429 n.22 (1984), the Court in dictum described Article 34 of the Refugee Convention as "precatory and not self-executing." See also Tel-Oren v. Libyan Arab Republic, 726 F.2d 774, 809 (D.C. Cir. 1984) (Bork, J., concurring) ("Articles 1 and 2 [of the United Nations Chart.er] ... contain general 'purposes and principles,' some of which state mere aspirations and none of which can sensibly be thought to have been intended to be judicially enforceable at the behest of individuals."); Sei Fujii v. State, 242 P.2d 617, 619 n.2 (Cal. 1952) (UN Charter provision requiring states to "promot[e] and encourag[e] respect for human rights" not self-executing); Brief for the United States as Amicus Curiae at 9, Jaffe v. Snow (U.S. May 27, 1994) (No. 93-241) (arguing that an agreement between the United States and Canada "to cooperate to deter ... transborder abductions" is judicially unenforceable), cert. denied, 114 S.C. 2724 (1994).

${ }^{74}$ Marbury v. Madison, 5 U.S. (1 Cranch) 137, 170 (1803).

${ }^{75}$ For example, in Dennis v. Higgins, 498 U.S. 439, 448 (1991), the Supreme Court held that a statute cannot be enforced through 42 U.S.C. $\$ 1983$ (1988) if, rather than "creat[ing] an obligation," it "does no more than express a congressional preference for certain kinds of treatment."

${ }^{76}$ See, e.g., Pennhurst State Sch. \& Hosp. v. Halderman, 451 U.S. 1 (1981). The line in this context has not been a stable one; the most recent decisions appear to rely primarily on the presence or absence of congressional intent to make the provision judicially enforceable. See Suter v. Artist M., 503 U.S. 347 (1992). Such a standard, if adopted for treaties as well, would effectively collapse the intent-based non-self-execution category and the justiciability category. Depending on which presumption is adopted ( $c$. part II, " 'Intent-Based' NonSelf-Execution in the Lower Courts," supra), this would either drastically expand or drastically reduce the judicial enforceability of treaties.

${ }^{77}$ Although the Foster and Percheman Courts did not require evidence that the parties had specifically considered whether an act of Congress was required, the question, as the Court conceived it in Foster, was whether such an intent could be inferred from the language of the treaty. There was nothing about the provision's ultimate objective (recognition of the validity of Spanish grants) that made it inherently judicially unenforceable; the provision was judicially unenforceable only because the parties to the treaty contemplated
} 
intent determines what the United States" obligation is (e.g., to "use its best efforts" to accomplish certain objectives), but the conclusion that the provision is not judicially enforceable results from notions about the appropriate role of courts in our domestic system.

Though this category of judicially unenforceable treaty differs in kind from the category recognized in Foster, its existence is constitutionally defensible - indeed, necessary. The Supremacy Clause allocates treaty-enforcement powers to the courts, but the power to enforce the law of the land was constitutionally allocated to the courts only in "cases of a Judiciary nature." "cooperate" to accomplish certain ends, or to "promote" or "encourage" them, requires the consideration and balancing of numerous disparate demands on our resources to determine what the "best" we can do under the circumstances is. The conclusion that, in our system of separated powers, this determination is not for the judiciary to make is so intuitive as to make the propriety of this category of judicially unenforceable treaty seem self-evident. ${ }^{79}$ It is nonetheless important to recognize that such treaties are judicially unenforceable not because of the intent of the parties (or anyone), but for domestic separation-of-powers reasons. Where the line is drawn between "precatory" (hence judicially unenforceable) and "obligatory" (hence judicially enforceable) treaty provisions is a matter of domestic constitutional law.

The unique hybrid domestic/international nature of treaty norms poses special challenges to courts attempting to draw that line. Treaty obligations might be thought by some to be "precatory" as a general matter because effective intermational enforcement mechanisms are lacking. The Founders, however, were well aware of the deficiencies of the international enforcement mechanisms; ${ }^{80}$ yet, by declaring treaties to be laws, they made them enforceable in our domestic courts so as to avert treaty violations attributable to the United States. The Supremacy Clause thus reflects a constitutional commitment by the United States to take its treaty obligations seriously notwithstanding their arguably precatory character in the international arena. In drawing the domestic-law line between precatory and obligatory treaty provisions, therefore, courts in this country should take care not to be unduly influenced by the modern realist tendency to regard treaties generally (like other forms of international law) as imperfectly obligatory. Courts should be aware that the line they draw between precatory and obligatory treaty provisions is purely one of domestic law, and in drawing that line they should keep in mind the Founders' intention, in adopting the Supremacy Clause, to transform what would otherwise have been imperfectly obligatory norms into judicially enforceable "laws."

\section{Indeterminateness and Non-Self-Execution}

The category of non-self-executing treaty that includes precatory and hortatory provisions may be expanded to encompass provisions that have been held to be unenforceable because they do not set forth sufficiently determinate standards for evaluating the conduct of the parties and their attendant rights and liabilities. This variant of the self-

that the objective would be achieved through legislation. Indeed, the very same treaty provision was held in Prrheman, 32 U.S. (7 Pet.) 51 (1833), to be judicially enforceable without legislative implementation. "Precatory $^{\text {"* }}$ provisions, by contrast, are judicially unenforceable without regard to the parties' intent concerning judicial enforcement.

is Ser 2 FiRRinn, supra note 60, at 430. See also 3 STORY, supra note 12, at 695 (Supremacy Clause directs courts to "enforce [treaties] directly in all cases, to which they can be judicially applied"). See generally Vázquez, supra note 2, at $1129-30$.

"Cf. Lon L. Fuller, The Forms and Limits of Adjudication, 92 Harv. L. Rev. 353 (1978).

"Sé Vázquez, supra note 2, at 1097-1101, 1124-25. 
execution issue originated in dicta from the Supreme Court's opinion in Head Money Cases, where the Court said that a treaty may be judicially enforced by private individuals when it "prescribes a rule by which the rights of the private citizen or subject may be determined." course of determining whether a given treaty is self-executing, whether the treaty is "too vague for judicial enforcement," 82 or "provide[s] specific standards," 83 or is "phrased in broad generalities" ${ }^{\prime 84}$ or "language of a broad and general nature." 85 The same idea seems to underlie the Restatement's assertion that a treaty is self-executing if it "can be readily given effect ... without further legislation."

These questions are not unique to treaties. The lack of "judicially discoverable and manageable standards" is often cited as bearing on whether statutory or constitutional provisions are judicially enforceable. ${ }^{87}$ This question is usually examined as part of the "political question" doctrine, but some commentators have argued that a court that declines to enforce a legal provision on political question grounds, like a court that declines to enforce a "precatory" law, is simply deciding on the merits that the law does not impose an obligation on the defendant or confer a correlative right on the plaintiff. ${ }^{88}$ Again, the conclusion that the treaty does not create "obligations" or "rights" disguises normative judgments about the role of the judiciary in our governmental system. ${ }^{89}$ In a

\footnotetext{
${ }^{81}$ Head Money Cases, 112 U.S. 580, 598-99 (1884). Some courts have read this language to stand for the proposition that a treaty may be enforced in the courts by individuals only if it establishes "private rights." This formulation of the "self-execution" test, however, is at best tautological and at worst misleading. See supra note 70. If the term "right" were understood in a particular way-i.e., as the obverse of a duty that is sufficiently determinate to be judicially enforced-then the "private right" interpretation and the "determinateness" interpretation offered in the text would be collapsed, but the concept of a "right" would do no work: the treaty's enforceability would turn on the precision with which the duty was defined; that the treaty conferred a "right" would simply follow from the conclusion that it was judicially enforceable. However, because there are innumerable competing senses of the term "right," see HENRY M. HART, JR., \& ALBERT M. SACKS, TIIE Legal Process: Basic Problems in the Maning and Application of Law 135 (William N. Eskridge, Jr., \& Phillip P. Frickey eds., 1994) (the term is "incorrigibly multifarious in actual usage"), I prefer, in the interest of clarity, to frame the "self-execution" test(s) without recourse to the term. Cf. infra text at note 89 (conclusion that treaty confers a "right" reflects judgments about the role of the courts in our governmental system).

${ }^{* 2}$ People of Saipan v. United States Dep't of Interior, 502 F.2d 90, 99 (9th Cir. 1974), cert. denied, 420 U.S. 1003 (1975).

${ }^{* 3}$ Diggs v. Richardson, 555 F.2d 848, 851 (D.C. Cir. 1976). In American Baptist Churche.s v. Meese, 712 F.Supp. 756, 770 (S.D. Cal. 1989), the court said that Article 1 of the 1949 Geneva Convention Relative to the Protection of Civilian Persons in Time of War was not a self-executing treaty provision because "[t]he language used does not impose any specific obligations on the signatory nations" (emphasis added). The court said that the lack of precision deprived the court of "any intelligible guidelines for judicial enforcement." See also Greenpeace USA v. Stone, 748 F.Supp. 749, 767 (D. Haw. 1990) (citing lack of "standards and procedures to judicially enforce the treaty"), appeal dismissed as moot, 924 F.2d 175 (9th Cir. 1991).

${ }^{84}$ Frolova v. Union of Soviet Socialist Republics, 761 F.2d 370, 374 (7th Cir. 1985). The cosurt concluded that such language "suggested that [the articles of the treaty] are declarations of principles, not a code of legal rights."

${ }_{85}$ United States v. Noriega, 808 F.Supp. 791,799 (S.D. Fla. 1992).

${ }^{86}$ RESTATEMENT (ThIRD), supra note $30, \$ 111$ reporters' note 5. A provision that prohibits clearly defined conduct on the part of the United States is perhaps the clearest example of a provision that "can readily be given effect" without further legislation. See Commonwealth v. Hawes, $76 \mathrm{Ky}$. (13 Bush) 697, 702-03 (1878), described by the Supreme Court as a "very able" decision, United States"v. Rauscher, 119 U S. 407, 427-28 (1886). See also RestatemENT (ThiRD), supra, \$111 reporters' note 5; Vázquez, supra note 2, at 1127. Cf. Vázquez, supra note 19 (describing [and criticizing] executive branch arguments that Article 33 of the Refugee Convention, which the United States agreed to comply with when it adhered to the Refugee Protocol, is not self-executing even though it prohibits clearly defined conduct). Even a treaty provision whose object is to prohibit clearly defined conduct would be non-self-executing if the parties so intended. See stipra note 41.

${ }^{87}$ Baker v. Carr, 369 U.S. 186, 217 (1962) (constitutional norms); Golden State Transit Corp. v. Los Angcles, 493 U.S. 103, 106 (1989) (constitutional and statutory norms judicially enforceable under 42 U.S.C. $\$ 1983$ if "not ... 'too vague and amorphous" " (quoting Wright v. Roanoke Redev. \& Hous. Auth., 479 U.S. 418, 431 (1987))).

${ }^{88}$ See Louis Henkin, Is There a Political Question Doctrine?, 85 YALE L.J. 597 (1976).

${ }^{84}$ See supra note 81 .
} 
sense, even "precatory" or "vague" treaty provisions impose obligations (and confer correlative rights): the obligation to attempt in good faith to bring about the contemplated ends and to act in conformity with even vague standards. Like the line between "precatory" and "obligatory" provisions, the line between "vague" and "manageable" standards is a domestic constitutional one that serves to allocate powers between the courts and the legislature and reflects judgments about the proper role of the courts in our governmental system.

That some such line must be drawn is certain. The Framers' constructive limitation of the judicial power to enforce laws to "cases of a Judiciary nature"90 contemplates a distinction between justiciable and nonjusticiable controversies. The vagueness of a treaty provision is surely relevant to its direct judicial enforceability, just as the vagueness of a constitutional or statutory provision is. A treaty provision setting forth a vague standard often leaves the parties with considerable discretion concerning the manner of bringing about the desired objective. If so, it might properly be concluded that, in our system of separated powers, determining how to achieve the desired objective is more appropriately a task for the legislative branch. ${ }^{91}$ But there may be imprecise treaty provisions that the judicial branch is well suited to enforce directly. For example, the "vagueness" of the Due Process and Equal Protection Clauses of the Constitution is not thought to render them judicially unenforceable. Thus, although relevant, the vagueness of a treaty provision is not necessarily dispositive of its direct judicial enforceability.

\section{Non-Self-Execution as Free-Wheeling Abstention}

Some lower courts have treated the self-execution inquiry as a more free-wheeling inquiry into the treaty's judicial enforceability, ${ }^{92}$ taking into account numerous factors in addition to precatoriness and indeterminateness. In People of Saipan, for example, the court listed the following factors as relevant to determining whether a treaty "establishes affirmative and judicially enforceable obligations without implementing legislation": "the purposes of the treaty and the objectives of its creators, the existence of domestic procedures and institutions appropriate for direct implementation, the availability and feasibility of alternative enforcement methods, and the immediate and long-range social consequences of self- or non-self-execution." ${ }^{\prime 3}$ This variant of the self-execution question thus appears to ask the courts to engage in an open-ended inquiry to determine on a case-by-case basis whether judicial enforcement of a particular treaty is a good idea. The test seems to resemble the ad hoc, quasi-discretionary abstention doctrine that some consider the political question doctrine to be. ${ }^{94}$ Like this understanding of the political question doctrine, this version of the self-execution

\footnotetext{
'H' See supra note 78.

"I Indeed, the Foster decision might have been decided on such grounds. As interpreted by the Court in that case, the relevant treaty provision obligated the United States to begin recognizing the Spanish grants as valid at some unspecified future date. As an alternative basis for its conclusion that the treaty was not judicially enforceable without legislative implementation, the Court might have said that the determination of the relevant time to begin recognizing the grants as valid requires the exercise of "political" judgment that, in our tradition, is not for the courts to make. If this had been the basis of the Court's judgment, a different result would have been called for if the treaty had stipulated that the United States "shall ratify the Spanish grants by January 1, 1824."

"- People of Saipan v. United States Dep't of Interior, 502 F.2d 90, 97 (9th Cir. 1974). Other courts have asked whether the treaty creates "judicially enforceable" or "privately enforceable" rights or rights of action or causes of action. See, e.g., Frolova v. Union of Soviet Socialist Republics, 761 F.2d 370, 374 (7th Cir. 1985); United States v. Thompson, 928 F.2d 1060, 1066 (11th Cir.), cert. denied, 112 S.Ct. 270 (1991), and cases cited supra note 67. These tests seem to combine the "justiciability" question (which I discuss in this part) and the private-right-of-action question (which I discuss in part $\mathrm{V}$ infra).

" 502 F.2d at 97.

"See Alexinder M. Bichet, The Least Dangerous Branch 125-26, 184 (1962).
} 
doctrine can be criticized as incompatible with our society's conceptions about what it means for a norm to have the status of "law," and, in particular, about the judiciary's role in enforcing norms having such status. ${ }^{95}$ But there are additional reasons to be troubled by these courts' apparent conception of the self-execution doctrine as an ad hoc, quasi-discretionary abstention doctrine.

Perhaps because the courts are cognizant of the tension between the political question doctrine and the Supremacy Clause, that doctrine has been restricted to relatively narrow limits. Only in exceptional cases is the doctrine even invoked, and it succeeds in only a fraction of those. The Supreme Court's decisions strongly suggest that the self-execution question is similarly relevant only in exceptional cases. The Court has unambiguously denied relief on self-execution grounds in only one case, ${ }^{96}$ as an alternative holding, ${ }^{97}$ and it reversed that decision only four years later ${ }^{98}$ In countless cases, the vast majority of those raising treaty-based claims, the Court has resolved the case without even mentioning the self-execution issue..$^{99}$ Nevertheless, the lower courts in recent years have treated self-execution as a threshold issue to be addressed in every treaty case. Asking the courts to determine as a threshold matter on an ad hoc basis in every treaty case whether the treaty should be judicially enforceable threatens to expand the doctrine "to new and uncharted fields." 100

A review of the lower-court self-execution decisions confirms the danger that courts applying this variant of the doctrine will lose sight of the Founders' design. As noted

\footnotetext{
${ }^{95}$ See Herbert Wechsler, Towards Neutral Principles of Constitutional Law, 73 HaRv. L. Rev. 1, 7-8 (1959).

${ }^{96}$ I refer here to Foster. Cameron Septic Tank Co. v. Knoxville, 227 U.S. 39 (1913), the only other case in which the Court may have denied relief on self-execution grounds, was ambiguous in this regard. In INS $v$. Stevic, 467.U.S. 407 (1984), the Court stated in dictum that Article 34 of the Refugee Convention was not self-executing. In the other cases in which the Court has mentioned the issue, the Court has either (1) found the treaty to be self-executing, see Trans World Airlines v. Franklin Mint Corp., 466 U.S. 24\$, 252 (1984); Bacardi Corp. v. Domenech, 311 U.S. 150 (1940); Cook v. United States, 288 U.S. 102 (1932); Asakura v. City of Seattle, 265 U.S. 332 (1924); United States v. Rauscher, 119 U.S. 407 (1886); United States v. Forty-Three Gallons of Whiskey, 93 U.S. (3 Otto) 188 (1876), or (2) denied relief on the basis of the last-iri-time rule, see
} Head Money Cases, 112 U.S. 580 (1884).

${ }_{97}$ See supra note 35.

${ }^{98}$ Percheman, 32 U.S. (7 Pet.) 51 (1833).

${ }^{99}$ See, e.g., Kolovrat v. Oregon, 336 U.S. 187 (1961); Clark v. Allen, 331 U.S. 503 (1947); Factor v. Laubenheimer, 290 U.S. 276 (1933); Nielsen v. Johnson, 279 U.S. 47 (1929); Jordan v. Tashiro, 278 U.S. 123 (1928); Patsone v. Pennsylvania, 232 U.S. 138 (1914); Tucker v. Alexandroff, 181 U.S. 619 (1901); Florida v. Furman, 180 U.S. 402 (1901); Lem Moon Sing v. United States, 158 U.S. 538 (1895); Ekiu v. United States, 142 U.S. 457 (1891); Botiller v. Dominguez, 130 U.S. 238 (1889); Wildenhus' Case, 120 U.S. 1 (1886); Chew Heong v. United States, 112 U.S. 536 (1884); Hauenstein v. Lynham, 100 U.S. 483 (1879); The Cherokee Tobacco, 78 U.S. (11 Wall.) 616 (1870); Wilson v. Wall, 73 U.S. (6 Wall.) 83 (1867); The Kansas Indians, 72 U.S. (5 Wall.) 737 (1866); Crews v. Burcham, 66 U.S. (1 Black) 352 (1861); Doe v. Wilson, 64 U.S. (23 How.) 457 (1859); United States v. Rogers, 45 U.S. (4 How.) 567 (1846); Porterfield v. Clark, 43 U.S. (2 How.) 76 (1844); Holmes v. Jennison, 39 U.S. (14 Pet.) 540 (1840); Strother v. Lucas, 31 U.S. (6 Pet.) 763 (1838); Cherokee Nation v. Georgia, 30 U.S. (5 Pet.) 1 (1831); Carneal v. Banks, 23 U.S. (10 Wheat.) 181 (1825); Hughes \%. Edwards, 22 U.S. (9 Wheat) 489 (1824); Orr v. Hodgson, 17 U.S. (4 Wheat.) 453 (1819); Chirac v. Chirac, 15 U.S. (2 Wheat) 259 (1817); Harden v. Fisher, 14 U.S. (1 Wheat) 300 (1816); Fairfax's Devisee v. Hunter's Lessce, 11 U.S. (7 Cranch) 603 (1812); Ware v. Hylton, 3 U.S. (3 Dall.) 199 (1796).

There are, of course, possible alternative explanations for the infrequency with which the Sispreme Court has addressed the selfexecution question. In some of the cases cited above, the litigant relying on the treaty lost on other grounds, and there was accordingly no need to reach that issue. Moreover, by denying certiorari in cases in which the lower courts have dismissed on self-execution grounds, the Court may be tacitly approving the results, if not the reasoning, of those decisions. Nevertheless, the fact that the Court has not addressed the doctrine in many years despite the glaring need for clarification, but has instead gone out of its way to avoid reaching forcefully pressed self-execution arguments by dismissing treaty-based claims on other (cxcecdingly tenuous and controversial) grounds, see, e.g., Sale v. Haitian Centers Council, 113 S.Ct. 2549 (1993); United States v. Alvarez-Machain, 504 U.S. 655 (1992), is itself strong evidence of the doctrine's problematic status.

${ }^{1(x)}$ The Court used this phrase in rejecting a conception of the act of state doctrine as a vague, quasidiscretionary abstention doctrine requiring an open-ended, case-by-case inquiry similar to that required by 
above, the Founders envisioned a central role for the courts in the enforcement of federal laws (including treaties). Because the courts are frequently called upon to enforce the Constitution and federal statutes, they are comfortable with their constitutional role in enforcing these categories of laws and accordingly have narrowly restricted the political question doctrine. But because the lower courts are less accustomed to enforcing treaties and tend to regard foreign relations questions as the province of the other branches, they have typically been exceedingly timid in enforcing treaties, particularly when individuals have sought to enforce them against the executive branch of the federal Government. ${ }^{101}$ A doctrine that effectively asks the courts to decide on a treaty-by-treaty basis whether treaties should be "judicially enforceable" and provides little guidance on the question is thus likely to result in a far more restricted judicial role than the Constitution contemplates.

What is needed is the articulation of a constitutional standard to differentiate the types" 10 of treaty provisions that are "addressed" as a constitutional matter to the legislature from those that are judicially enforceable without legislative elaboration. It will likely be impossible to arrive at a broadly applicable formulation that does not leave a great deal to incremental judicial development. Factors other than "precatoriness" and "vagueness" will no doubt be relevant. ${ }^{103}$ It may even be that certain treaties are not judicially enforceable under our Constitution because they bear too closely on national security or are otherwise too sensitive for judicial involvement. A claim that an arms control agreement requires the United States to dismantle weapons, for example, might be nonjusticiable on this ground even if the agreement is neither precatory nor vague. These are questions for another day. Giving content to the distinction between judicially enforceable and judicially unenforceable treaty obligations will take time, but the project cannot meaningfully begin until we clearly distinguish the "justiciability" from the "intent-based" branch of the self-execution doctrine and recognize that what is called for in the "justiciability" cases is a constitutional separation-of-powers decision analogous to a political question decision. In the meantime, perhaps the most we can expect is that the courts use an appropriate baseline in making their "justiciability" decisions: taking due account of the central role that the Constitution assigns them in the enforce-

the vew of the selfexecution doctrine discussed in text. W.S. Kirkpatrick \& Co. v. Environmental Tectonics Corp., 493 U.S. 400, 409 (1990).

111. Lower-court decisions in the three lawsuits seeking to enjoin the Haitian interdiction program as a violation of the Refugee Protocol illustrate this timidity. In both Haitian Refugee Center v. Gracey, 600 F.Supp. 1396,1406 (D.D.C. 1985), and Haitian Centers Council v. McNary, No. 92-CV-1258, slip op. at 8 (E.D.N.Y. June 5), rev'd on other grounds, 969 F.2d 1350 (2d Cir. 1992), rev'd sub nom. Sale v. Haitian Centers Council, 113 S.Ct. 2549 (1993), the district court denied relief on the ground that the Refugee.Protocol was not selfexecuting, and in Haitian Refugee Center v. Baker, 949 F.2d 1109 (11th Cir. 1991), cert. denied, 502 U.S. 1122 (1992), the court of appeals denied relief on the same ground. It is noteworthy that, when the Supreme Court finally confronted the challenge to the interdiction program, it did not question the Protocol's judicial enforceability, even though the Executive forcefully urged the Court to hold that the Protocol was not selfexecuting. Sale, supra. On the selfexecuting character of the Refugee Protocol, see generally Vázquez, supra note 19.

"1": An important difference between this category of non-self-executing treaty and the Foster category is that a justiciability-based determination that a treaty is judicially unenforceable will affect not just the particular treaty provision before the court, but all provisions "like" it. Determining that a treaty is not judicially enforceable for reasons other than intent requires a constitutional separation-of-powers judgment; a determination that one treaty provision is not judicially enforceable will accordingly affect all relevantly similar treaty provisions. By contrast, the parties to the treaty (or perhaps the U.S. treaty makers unilaterally) may make a treaty judicially unenforceable for any (rational) reason; their determination that one treaty shall not be judicially enforceable will not have any necessary implications with respect to the judicial enforceability of other treaties.

I"' If some "vague" treaty provisions may be suitable for direct judicial enforcement while others are not, see supra text following note 91 , distinctions among such provisions will obviously have to be based on factors other than vagueness. 
ment of treaties, they should hold treaty provisions to be judicially unenforceable only if there are exceptional and compelling reasons for doing so.

\section{The "Constitutionality" Doctrine}

It is often said that a treaty is not self-executing if it purports to accomplish what is within the exclusive lawmaking power of Congress. Although there is no "definitive" judicial authority for this proposition, ${ }^{104}$ the proposition is unproblematic from the standpoint of the Supremacy Clause. It is well accepted, for example, that the treatymaking power is subject to the Bill of Rights. ${ }^{105}$ Thus, a treaty that purports to restrict the freedom of speech in a way that would not be consistent with the First Amendment if the restriction had been enacted by Congress would not be enforceable in the courts for the same reason that an unconstitutional statute would not be. There is little difficulty in concluding that a treaty that purports to accomplish what lies beyond the treatymaking power for other reasons is similarly not enforceable in the courts.

If Congress possesses the power to accomplish what the treaty makers agreed to do but lack the power to accomplish, then the treaty might be thought of as "non-selfexecuting." Compliance by the United States with the treaty is not impossible, but the Constitution requires an act of Congress. ${ }^{106}$ But this category of non-self-executing treaty differs significantly from the categories discussed above. It differs from the Foster category in that the treaty's non-self-executing character does not depend on the intent of the parties or the treaty makers (or anyone). Instead, the treaty is non-self-executing because of the treaty makers' constitutional disability. The "constitutionality" version of the doctrine is similar to the "justiciability" version in that both require judgments about constitutional allocations of powers, but the "justiciability" version requires a judgment about the distribution of the power to enforce particular types of treaty provisions between the courts and the legislature, while the "constitutionality" version requires a judgment about the distribution of the power to accomplish certain ends between the treaty makers and the lawmakers.

The dearth of case law on the "constitutionality" version of the doctrine indicates that this category is of limited practical significance. The types of treaties that have been considered non-self-executing for constitutional reasons include treaties that purport to raise revenue, ${ }^{107}$ treaties that purport to make conduct criminal, ${ }^{108}$ and treaties that purport to appropriate money. ${ }^{109}$ Whether these conclusions are sound, and whether there are other powers that the lawmakers possess but the treaty makers lack, are beyond the scope of this article.

Courts sometimes consider the subject matter of a treaty to be relevant to the selfexecution issue even though there is no question about the treaty makers' constitutional power to accomplish the contemplated objective. Thus, it is often said that treaties of

${ }^{104}$ See Restatement (THiRD), supra note $30, \$ 111$ reporters' note 6.

${ }^{105}$ See HeNkIN, supra note 37, at 137-56, 251-70.

${ }^{106}$ See Paust, supra note 1, at 775-81; HenRY J. Steiner, DetLev F. VAGts \& Harold Hongju Koil, InTERNA. TIONAL Legal Problems 556-57 (4th ed. 1994).

${ }_{107}$ See RestaTEMENT (THIRD), supra note $30, \$ 111 \mathrm{cmt}$. $i$; Edwards v. Carter, 580 F.2d 1055, 1058 (D.C. Cir. 1978); The Over the Top, 5 F.2d 838, 845 (D. Conn. 1925). But see Paust, supra note 1, at 778, 780-81.

${ }^{108}$ Restatement (THIRD), supra note $30, \$ 111 \mathrm{cmt}$ i; Iwasawa, supra note 1, at $676 \mathrm{n} .239$; Hopson v. Krebs, 622 F.2d 1375, 1380 (9th Cir. 1980) ("Treaty regulations that penalize individuals ... are generally considered to require domestic legislation before they are given any effect."). But see Paust, supra note 1, at 775, 780. In The Over the Top, 5 F.2d at 845, the court said that "[i]t is not the function of treaties to enact the ... criminal law of a nation. For this purpose no treaty is self-executing."

${ }^{109}$ See Restatement (THIRD), supra note $30, \S 111 \mathrm{cmt}$. i. But see Paust, supra note 1 , at 775, 778, 780-81. 
friendship, commerce and navigation are self-executing; ${ }^{110}$ it has also been said that extradition treaties are by their nature self-executing ${ }^{111}$ and, inconsistently, that they are non-self-executing. ${ }^{122}$ Under the analysis proposed in this article, the relevance of a treaty's subject matter to its self-executing character will vary depending on which selfexecution doctrine is involved. Subject matter would appear to be irrelevant under Foster. Indeed, the very treaty found to be non-self-executing in Foster was later held to be selfexecuting. What matters under Foster is the presence or absence of an intent to require legislation. Subject matter should generally also be irrelevant under the broader "justiciability" version of the doctrine. This version of the doctrine holds a treaty to be non-selfexecuting if the obligation the treaty imposes is one that is not amenable to enforcement by the courts. In the prototypical case, the focus will be on the nature of the provision (precatory versus obligatory; vague versus determinate), not the substantive topic to which the provision relates. It may be, however, that the sensitivity of a treaty's subject matter can render it nonjusticiable in certain circumstances. ${ }^{113}$ With this possible exception, the subject matter of a treaty, as distinguished from the nature of the obligation, should be relevant to the self-execution issue only to the extent the Constitution places that subject beyond the scope of the treaty-making power.

\section{The "PrRAte Right of Action" Doctrine}

Increasingly in recent years, the "self-execution" question has been said by the courts to concern whether the treaty being invoked confers a "private right of action." may be conceded that private parties may maintain an action in court to enforce a treaty provision only if they possess a right of action. It is a mistake, however, to assume that a treaty may be enforced in court by private parties only if it confers a private right of action itself. Many treaties, like most constitutional provisions and many federal statutes, do not themselves purport to confer private rights of action. Instead, they typically impose primary obligations on individuals (including government officials) without expressly addressing matters of enforcement. ${ }^{115}$ A treaty that does not itself address private enforcement is no less judicially enforceable by individuals than consti-

\footnotetext{
I"' Spiess v. C. Itoh \& Co. (America), 643 F.2d 353, 356 (1981), cert. dismissed, 454 U.S. 1130 (1982). See Alona E. Evans, Self-Executing Treaties in the United States of America, 30 BRrT. Y.B. INTL L. 178, 186 (1953) (listing 12 subjects normally considered to be self-executing, including "unconditional most-favoured-nation provisions of commercial treaties").

"I See United States v. Caro-Quintero, 745 F.Supp. 599, 607 (C.D. Cal. 1990) ("Extradition treaties by their nature are deemed self-executing and thus are enforceable without the aid of implementing legislation."), affd $s u b$ nom. United States v. Alvarez-Machain, 946 F.2d 1466 (1991), rev'd on other grounds, 504 U.S. 655 (1992); In re Extradition of McMullen, 769 F.Supp. 1278, 1293 (S.D.N.Y. 1991).

"L. Terlinden v. Ames, 184 U.S. 270, 288 (1902) ("Treaties of extradition are executory in their character, and fall within the rule laid down by Chief Justice Marshall in Foster v. Neilson ..." (dictum)).

"See text following note 103 supra.

"' See Smith v. Socialist People's Libyan Arab Jamahiriya, 1995 U.S. Dist. LEXIS 6817, at *11 n.6 (E.D.N.Y. May 17, 1995); Telesat de Panama v. United States Dept. of Defense, 1992 U.S. App. LExIS 18469, at*17 (Fed. Cir. Aug. 7, 1992); Goldstar (Panama), S.A. v. United States, 967 F.2d 965, 968 (4th Cir. 1992); United States v. Thompson, 928 F.2d 1060, 1066 (11th Cir. 1991); Columbia Marine Servs., Inc. v. Reffet Ltd., 861 F.2d 18, 21 (2d Cir. 1988); United States v. Bent-Santana, 774 F.2d 1545, 1550 (11th Cir. 1985); Tel-Oren v. Libyan Arab Republic, 726 F.2d 774, 808 (D.C. Cir. 1984) (Bork, J., concurring); Mannington Mills, Inc. v. Congoleum Corp. 595 F.2d 1287, 1298-99 (3d Cir. 1979); Dreyfus v. Von Finck, 534 F.2d 24, 30 (2d Cir. 1976); United States v. Noriega, 808 F.Supp. 791, 798 (S.D. Fla. 1992); Greenpeace USA v. Stone, 748 F.Supp. 749,767 (D. Haw. 1990); Handel v. Artukovic, 601 F.Supp. 1421, 1425 (C.D. Cal. 1985). Cf. Argentine Republic v. Amerada Hess Shipping Corp., 488 U.S. 428, 440-42 (1989) (citing Foster and Head Money Cases in support of proposition that certain treaties do not confer private causes of action).

"I: Ser Paul M. Bator et al., HaRT ANd WechSler's The Federal Courts and the Federal System 533 (3d cd. 1988) ("Federal law is generally interstitial in its nature. ... [Often,] substantive rights [are] defined by Congress but the remedies for their enforcement left undefined or relegated wholly to the states.").
} 
tutional or statutory provisions that do not themselves address private enforcement. The "private right of action" to enforce a treaty may have its source in laws other than the treaty itself."

By virtue of the Supremacy Clause, all treaties that are self-executing in the first three senses of the term operate to nullify inconsistent state laws and prior federal laws. Thus, even without a "private right of action," private individuals may enforce such treaties defensively if they are being sued or prosecuted under statutes that are inconsistent with treaty provisions. ${ }^{117}$ Additionally, treaties may be supplemented by the common law ${ }^{118}$ and by state statutes that confer "rights of action." "19 Thus, if an individual's liberty or property has been taken in a manner that contravenes a treaty provision, that individual may enforce the treaty in court through common-law forms of action or statutory provisions that authorize lawsuits to challenge deprivations of such liberty or property interests. Because the Supremacy Clause prohibits the states from discriminating against federal law, ${ }^{120}$ such common-law or statutory rights of action must be made available by the states to redress deprivations that violate treaties if they are available to redress similar deprivations that violate state law. Finally, rights of action to enforce treaty provisions may be supplied by federal statutes. ${ }^{121}$ For example, extradition treaties are typically enforced through habeas corpus petitions. ${ }^{122}$ Additionally, federal statutes such as section 1983 and the Administrative Procedure Act (APA) confer rights of action to enforce federal laws (including treaties) against state and federal officials, respectively. ${ }^{123}$

The judicial opinion most often cited for the proposition that a treaty is "self-executing" and hence judicially enforceable only if it creates a private right of action ${ }^{124}$ came in a case in which there was no apparent source outside the treaty for the plaintiff's right of action. In Tel-Oren v. Libyan Arab Republic, private parties sued to recover damages for injuries allegedly caused in Israel by the terrorist acts of the defendants. ${ }^{125}$ Having concluded that the Alien Tort Statute did not confer a right of action, Judge Bork, in his concurring opinion, considered whether a right of action could be found in the treaties invoked by the plaintiffs. If the attack had occurred in the United States, the court could probably have found a right of action in state tort law. ${ }^{126}$ If the lawsuit had

\footnotetext{
${ }^{116}$ In other words, a treaty that does not itself create a private right of action might be described as nonself-executing in the sense that a plaintiff seeking to maintain an action must find some other law to supplement the treaty, see infra note 134, but the "other law" need not be federal, or statutory, or later in time than the treaty.

${ }^{117}$ See, e.g., Kolovrat v. Oregon, 336 U.S. 187, 197 (1961); Patsone v. Pennsylvania, 232 U.S. 138, 145 (1914).

118 Throughout our nation's existence, treaties have been enforced in court through commion-law forms of action, such as actions in debt and actions in the nature of ejectment. Florida v. Furman, 180 U.S. 402,428 (1901) (action to remove cloud on legal title); Botiller v. Dominguez, 130 U.S. 238, 243 (18(39) (ejectment); Orr v. Hodgson, 17 U.S. (4 Wheat.) 453, 462-63 (1819) (bill in equity); Chirac v. Chirac, 15 U.S. (2 Whcat.) 259, 277 (1817) (ejectment); Harden v. Fisher, 14 U.S. (1 Wheat.) 300, 303 (1816) (same).

${ }^{119}$ Jordan v. Tashiro, 278 U.S. 123, 125 (1928) (state mandamus action); Asakura v. City of Seattle, 265 U.S. 332, 340 (1924) (state action for injunction); Hauenstein v. Lynham, 100 U.S. 483, 485 (1879) (action "pursuant to a law of the State").

${ }^{120}$ See, e.g., Testa v. Katt, 330 U.S. 386 (1947); McKnett v. St. Louis \& S.F. Ry., 292 U.S. 230, 233-34 (1934).

121 See, e.g., United States v. Rauscher, 119 U.S. 407 (1886) (federal habeas corpus action); Bildwin v. Franks, 120 U.S. 678 (1887) (civil rights legislation). See generally Vázquez, supra note 2, at 1146-54 (discussing availability of $\$ 1983$ and Administrative Procedure Act as rights of action for enforcing treaty obligations).

${ }_{1: 22}$ See, e.g., Rauscher, 119 U.S. 407 (1886).

${ }^{123}$ See generally Vázquez, supra note 2, at 1143-56.

${ }^{124}$ Though there were cases before Tel-Oren v. Libyan Arab Republic, 726 F.2d 774 (D.C. Cir. 1984), that equated the self-execution issue and the private-right-of-action issue, see Mannington Mills, Inc. v. Congoleum Corp., 595 F.2d 1287, 1298-99 (3d Cir. 1979); Dreyfus v. Von Finck, 534 F.2d 24, 30 (2d Cir. 1976), Tel-Oren appears to have become the standard citation for this equivalency. See cases cited supra note 114.

726 F.2d at 775.

${ }^{126}$ Because the attack occurred in Israel, it was unlikely that any state's tort law applied to such conduct. The question of federal jurisdiction would of course have been a separate issue.
} 
been brought in state court, the court could have considered whether Israeli law conferred a right of action. ${ }^{127}$ But because the lawsuit was brought in federal court and federal jurisdiction was premised on the "arising under" statute, a federal right of action was necessary. ${ }^{128}$ Since the defendants were not state or federal officials, neither section 1983 nor the APA conferred a right of action, and (in light of Judge Bork's interpretation of the Alien Tort Statute) no other federal statute gave the plaintiffs a federal right of action for damages. Under these circumstances, it was appropriate for the court to consider whether the treaty itself conferred a private right of action. ${ }^{129}$

Unfortunately, however, Judge Bork created much confusion by equating the "right of action" issue with the "self-execution" issue, and by erroneously writing that, "[a]bsent authorizing legislation, an individual has access to courts for enforcement of a treaty's provisions only when the treaty ... expressly or impliedly provides a private right of action."1:31" Subsequent courts have relied on this dictum in cases in which there should have been no occasion to ask whether the litigant relying on the treaty had a "right of action." For example, in the recent criminal prosecution of Manuel Noriega, the district court stated that certain treaties Noriega was relying on would be "self-executing" and thus enforceable by the court only if they created a "private right of action."131 Defendants relying on a treaty as a defense to a criminal prosecution (or claiming that the treaty governs the conditions of their confinement) do not need a "private right of action," as they are not seeking to maintain an action. ${ }^{132}$

This is not the place to discuss what criteria should determine whether a treaty confers a right of action. ${ }^{133}$ It is important to note, however, that this issue is analytically distinct from the "self-execution" concept introduced in Foster and even from the broadened "justiciability" version of the doctrine derived from Head Money Cases. ${ }^{134}$ Given the existence of common-law and statutory rights of action for the enforcement of federal

${ }^{1: 27}$ However, a state court might have dismissed such a suit on the ground of fomum non conveniens, an issue that would be governed by state law. See American Dredging Co. v. Miller, 114 S.Ct. 981 (1994).

${ }_{12}$ That would certainly be true today under the Supreme Court's interpretation of 28 U.S.C. $\$ 1331$ in Merrell Dow Pharmaceuticals, Inc. v. Thompson, 478 U.S. 804 (1986). Thus, the court's statement in Columbia Marine Servs., Inc. v. Reffet Ltd., 861 F.2d 18, 21 (2d Cir. 1988), that "[a]n action arises under a treaty [for purposes of $\$ 1331$ ] only when the treaty expressly or by implication provides for a private right of action" was accurate when made, though it might have been contestable before Merrell Dow.

${ }_{1 * 4}$ Other courts that have considered whether a treaty confers a private right of action have similarly done so in circumstances in which there was no other apparent source for the judicial remedy sought by the plaintiff. See Handel v. Artukovic, 601 F.Supp. 1421, 1425 (C.D. Cal. 1985) (suit for damages for injuries occurring in Yugoslavia).

i"Tel-Oren, 726 F.2d at 808. Even if we interpreted the term "authorizing legislation" broadly to include state statutes and generic federal statutes such as the habeas corpus statutes, this statement would be erroneous because it fails to recognize that a right of action to enforce a treaty may have sources other than legislation; it may, for example, have its source in the common law or in another treaty.

11 United States v. Noriega, 808 F.Supp. 791, 798 (S.D. Fla. 1992). The court held that the treaties were selfexecuting.

${ }^{1 / 2}$ The court in United States v. Bent-Santana, 774 F.2d 1545, 1550 (11th Cir. 1985), similarly discussed whether the treaty gave a criminal defendant a right of action. If a prisoner after conviction wishes to challenge the conditions of his confinement on the ground that they violate the U.S. treaty obligations, the habeas corpus statutes confer the relevant "right of action."

' On this question, see Vâzquez, supra note 2, at 1155-62.

1 The Restatement takes the position that "[w] hether a treaty is self-executing is a question distinct from whether the treaty creates private rights or remedies." RESTATEMENT (THIRD), supra note $30, \$ 111 \mathrm{cmt}$. $h$. In reality, a treaty that does not itself confer a private right of action can accurately be described as non-selfexecuting, as that term is used in legal discourse. See Vázquez, supra note 2, at 1117-18 (citing such uses of the term). As I have argued elsewhere, the variety of ways in which the term can be used contributes to the confusion surrounding the self-execution "doctrine." See id. If, however, the Restatement means that the distinction introduced in Foster did not relate to the existence or nonexistence of a private right of action, it is correct. 
laws, whether a treaty itself confers a "private right of action" is a question that should have to be faced in only a subset of treaty cases. ${ }^{135}$

\section{CONCLUSION}

The distinction between self-executing and non-self-executing treaties has particularly confounded the lower courts, whose decisions on the issue have produced a body of law that can only be described as being in a state of disarray. Much of the problem is the result of sloppy reasoning and careless use of precedent. For example, the Ninth Circuit recently dismissed a treaty argument out of hand with a simple citation to a Supreme Court footnote stating that a different provision of the treaty was not "self-executing." 136 (As noted, ${ }^{137}$ it is well accepted that certain provisions of a treaty may be self-executing while others are not.) But even the courts that have been somewhat more conscientious in attempting to classify treaties according to Chief Justice Marshall's distinction have been confounded by the unusual hybrid domestic/international nature of the distinction. Unfortunately, they have had little guidance from the Supreme Court, which has not said more than a sentence or two about the distinction in any case for nearly a century.

The confusion is ultimately attributable to the expansion by some lower courts of Chief Justice Marshall's distinction to embrace related, though distinct, issues that are not unique to treaties. Addressing distinct issues through a single "doctrine" has inevitably, and predictably, resulted in disarray. For example, decisions correctly dismissing claims on the ground that the treaty on which the plaintiff relied did not create a private right of action, and in the process labeling the treaty as non-self-executing, have subsequently been relied on, erroneously, to reject the arguments of a litigant relying on the treaty by way of defense. ${ }^{138}$ And "justiciability" decisions stating that a treaty's self-executing character is a matter for the courts to decide independently (a correct statement if confined to this version of the self-execution issue) will be erroneously relied on for the proposition that the intent of U.S. officials regarding judicial enforceability is not dispositive of, or even relevant to, the self-execution issue. ${ }^{139}$

Bringing coherence and analytical clarity to this area of the law requires recognition that the self-execution "doctrine" addresses at least four distinct types of reasons why a treaty might be judicially unenforceable. First, a treaty might be judicially unenforceable because the parties (or perhaps the U.S. treaty makers unilaterally) made it judicially unenforceable. This is primarily a matter of intent. Second, a treaty might be judicially unenforceable because the obligation it imposes is of a type that, under our system of

\footnotetext{
${ }^{135}$ The issue of standing or "invocability" of a treaty provision has often been examined as a self-execution issue. See Jackson, supra note 2, at 158-59. The standing issue is closely related to the right-of-action issue. To the extent we continue to regard standing as a self-execution issue, we may regard it as a branch of the "private right of action" version of that doctrine. As I have addressed standing to enforce treaties at length elsewhere, see Văzquez, supra note 2, I shall not discuss it here except to note that, at a minimum, anyone whose commonlaw liberty or property interests are being impaired through a violation of a treaty should be deemed to have standing to enforce the treaty in court. See generally id. For example, someone kidnapped from Mexico by federal officials and being held in the United States necessarily has standing to enforce in our courts a treaty provision prohibiting such abductions and requiring the return of the abductee, if the treaty is self-executing. Cf. United States v. Alvarez-Machain, 504 U.S. 655, 667 (1992), quoted supra note 25.

is6 See United States v. Aguilar, 883 F.2d 662, 680 (9th Cir. 1989), cert. denied, 111 S.Ct. 751 (1991).

197 See text at note 65 supra.

${ }^{139}$ See United States v. Noriega, 808 F.Supp. 791, 798 (S.D. Fla. 1992), and United States \%. Bent-Santana, 774 F.2d 1545, 1550 (11th Cir. 1985), discussed supra in text at and notes 131 and 132.

${ }_{139}$ See Report of the Committee on Human Rights, Annex D, Committee Letter to Senator Claibonte Pell (Dec. 11, 1991), AM. Branch INT'L L. Ass'N, Proc. \& CommitTeE Rep. 1991-1992, at 98, 111 \& n.26, 112 \& n.28 (1992), quoted in Paust, supra note 61, at 1265-66.
} 
separated powers, cannot be enforced directly by the courts. This branch of the doctrine calls for a judgment concerning the allocation of treaty-enforcement power as between the courts and the legislature. Third, a treaty might be judicially unenforceable because the treaty makers lack the constitutional power to accomplish by treaty what they purported to accomplish. This branch of the doctrine calls for a judgment about the allocation of legislative power between the treaty makers and the lawmakers. Finally, a treaty provision might be judicially unenforceable because it does not establish a private right of action and there is no other legal basis for the remedy being sought by the party relying on the treaty. Unlike the first three categories of non-self-executing treaties, a treaty that is non-self-executing in the fourth sense will be judicially unenforceable only in certain contexts. These four issues are sufficiently distinct and require sufficiently differing analyses that they should be thought of as four distinct doctrines. ${ }^{140}$

If integrity is to be restored to this area of the law, the courts must recognize that the terms "self-executing" and "non-self-executing" do not have a unique meaning with respect to treaties. In examining "self-execution" arguments, the courts should therefore carefully consider the precise reason that the particular treaties before them are claimed to be judicially unenforceable, and in deciding the issue they should rely only on precedents involving that issue. Finally, and most importantly, the courts should decide the issue in full cognizance of the central role that the Constitution assigns to them in the enforcement of treaties.

\footnotetext{
1" We might add to the list of "doctrines" of self-executing treaties by including categories for treaties that fail to accomplish certain other things that a litigant might need in particular circumstances to maintain an action. For example, to sue a government entity, a litigant may require a waiver or withdrawal of sovereign immunity. A treaty that does not waive or withdraw such immunity might be described as "non-self-executing." See Argentine Republic v. Amerada Hess Shipping Corp., 488 U.S. 428, 442 (1989).
} 